\title{
The founding of Aboriginal History and the forming of Aboriginal history
}

\author{
Bain Attwood
}

Nearly 40 years ago an important historical project was launched at The Australian National University (ANU). It came to be called Aboriginal history. It was the name of both a periodical and a historiographical movement. In this article I seek to provide a comprehensive account of the founding of the former and to trace something of the formation of the latter. ${ }^{1}$

Aboriginal history first began to be formed in the closing months of 1975 when a small group of historically-minded white scholars at ANU agreed to found what they described as a journal of Aboriginal History. At that time, the term, let alone the concept of Aboriginal history, was a novel one. The planners of this academic journal seem to have been among the first to use the phrase in its discursive sense when they suggested that it 'should serve as a publications outlet in the field of Aboriginal history'.2 Significantly, the term was adopted in the public realm at much the same time. The reports of the Committee of Inquiry on Museums and National Collections (the Pigott Report) and the Planning Committee on the Gallery of Aboriginal Australia, which were the outcome of an inquiry commissioned by the Whitlam Labor Government in order to articulate and give expression to a new Australian nationalism by championing a past that was indigenous to the Australian continent, both used the term. ${ }^{3}$ As

1 I wish to thank Niel Gunson, Bob Reece and James Urry for allowing me to view some of their personal papers concerning Aboriginal History; Russell Taylor, Principal of the Australian Institute of Aboriginal and Torres Strait Islander Studies, for granting me access to the records of its Publications Committee; Eleanor Galvin, Senior Reference Librarian, Australian Institute of Aboriginal and Torres Strait Islander Studies, for facilitating my access to papers held by the Institute; the late Dick Barwick, Stephen Foster, Niel Gunson, Luise Hercus, Isabel McBryde and Peter Read for discussing aspects of the journal's work with me; Peter Corris' literary agent Gaby Naher, Ann Curthoys, Niel Gunson, Ken Inglis, Andrew Markus, Nicolas Peterson, Bob Reece, Lyndall Ryan, James Urry and Wang Gungwu for patiently answering my questions via email; and Jeremy Beckett, Adam Clulow, Jane Drakard, Stephen Foster, Niel Gunson, Claudia Haake, Luise Hercus, Ken Inglis, Ernest Koh, Isabel McBryde, Andrew Markus, Ruth Morgan, Seamus O'Hanlon, Marian Quartly, Peter Read, Bob Reece, Liz Reed, Noah Shenker, David Slucki, the late Tom Stannage, Alistair Thomson, James Urry and two anonymous referees for reading earlier versions of this article and providing me with a wealth of information and/or advice.

2 In an article one of the founders of the journal Peter Corris authored in 1967, he used the term 'Aboriginal History' several times but largely in its temporal sense. The term he adopted for the approach he recommended to this past was 'ethnohistory'. See Corris 1969: 203.

3 The Pigott Report was penned largely by the prehistorian John Mulvaney, whose 1969 book The Prehistory of Australia, had turned Australian history on its head, not least by asserting that 
these more or less simultaneous references to 'Aboriginal history' might suggest, the founding of a journal devoted to the subject was the product of a moment of ferment that was both scholarly and political in nature. ${ }^{4}$

In recent years the term 'Aboriginal history' has been used in a very general way. As the anthropologist Gillian Cowlishaw has argued, this is problematic since the focus of much the work bearing this moniker is not in fact the Aboriginal sphere but rather the British colonisers and their successors' treatment of Aboriginal people. In the period that Aboriginal History was being founded, 'Aboriginal history' had a very specific set of meanings that centred on the former word as well as the implications of a project that sought to join together the domains of Aboriginality and history. One of my purposes in the second part of this article is to recover those meanings. They were the subject of considerable and at times bitter debate among the founders of the journal. I recount the terms of this conflict and consider its outcomes, not least because the decision of the journal's editorial board to commit itself to a particular definition of Aboriginal history had a major impact on the journal's development and the directions it took. In the fourth and final section of this article I reflect upon this fact since it can be said to have lessened the amount of influence the journal might otherwise have had. More especially, I pinpoint what might be regarded as a fundamental problem in the enterprise of Aboriginal history, one which was probably inherent in its very nature, or at the very least a consequence of it being born of a certain historical moment and forged in particular historical circumstances. ${ }^{5}$

The founding of the journal, the subject of the first part of this article, owed much to the fact that there were a large number of scholars at ANU interested in the pre-colonial (pre-1788) and the post-colonial (post-1788) past of Aboriginal people; indeed, I suggest that a journal of this kind would not and could not have been formed anywhere else in Australia. I argue, moreover, that the nature of the journal was influenced in a relatively systematic manner by the disciplinary backgrounds of its key players, and in a somewhat haphazard way by the differing status of those disciplines in the Australian academy in respect of the study of Aboriginal people. More specifically, I contend that the background that the principal figures had in the areas in Pacific, Native American and Southeast Asian history was crucial to the way it evolved, not least because the study of the Aboriginal past had been neglected by historians of Australia. Most of the factors noted here, I seek to demonstrate, shaped the manner in which fundamental questions concerning the nature of the journal's project, as well as the nature of Aboriginal history as a historiographical enterprise, were addressed by the

the Aboriginal people were the country's first discoverers, explorers and colonists, and the historian Geoffrey Blainey, who had just published a popular, celebratory history of pre-colonial Aboriginal Australia, Triumph of the Nomads.

4 National Collections: Submission to Cabinet, 12 December 1973. National Archives of Australia, Series A5915, Item 846; Museums 1975: 16, 71, 73, 84, 87; Gallery 1975: 11, 25; Niel Gunson and Robert Reece, Circular letter on behalf of the Editorial Board, 11 November 1975, Barwick Papers, Series 17, Box 2, BARI02404, my emphasis. All further references to Barwick's Papers are to this series number unless otherwise stated.

5 Cowlishaw 2006: 182. 
founders of the journal. These questions included who should be its principal subjects and whose perspectives should be privileged; what sources or resources should be drawn upon and how should they be used; which disciplinary approaches were best suited to the task of recovering and representing this past; and should vernacular accounts of the past, especially Aboriginal ones, be regarded as merely sources for Aboriginal history or as histories in their own right? In one way or another, most of these questions raised a larger matter about authority, which proved difficult to resolve. ${ }^{6}$

The forming of new journals, it probably goes without saying, requires considerable forethought and much hard work. The name of Diane Barwick will be forever associated with Aboriginal History, and rightly so. As readers will see in the second part of this article, it is difficult to grasp the story of the journal's early years without attending to the role Barwick played and the influence she came to have on its direction. I have felt compelled to devote a third part to a consideration of Barwick's relationship to the journal and the toll this took upon her. ${ }^{7}$ At the same time one of my goals in writing this article has been to highlight the key role of Niel Gunson, who was the journal's founding and guiding figure, as this has tended to be submerged in previous accounts of the periodical. ${ }^{8}$

\section{Conceiving, planning and funding the journal}

Sometime in the 1960s Niel Gunson (1930- ) began to consider founding a journal devoted to the history of Australia's indigenous people. He had both a scholarly interest in the Aboriginal past, which owed much to his historical research on missionaries, and a humanitarian concern for contemporary Aboriginal people, which owed a good deal to his Congregational background. In 1959 he had completed a study of evangelical missionaries in the Pacific for a $\mathrm{PhD}$ at $\mathrm{ANU}$, and the following year, after being appointed to a lectureship at the University of Queensland, he undertook research on German Gossner missionaries who established at Zion Hill in the late 1830s one of the earliest missions in Australia. At the same time Gunson accompanied a white South African liberal leader, Margaret Ballinger, on a visit to Cherbourg, the largest of Queensland's Aboriginal reserves, during which she criticised the conditions and expressed the opinion that black South Africans were better off than Aboriginal Australians. 'This', he has recalled, 'made me think of my responsibility towards the Aboriginal people'. ${ }^{9}$

6 By the early 1980s Aboriginal people themselves were posing questions about who had the right to represent the Aboriginal past and demanding a say in determining how this history should be told and by whom, but this phenomenon followed the founding of Aboriginal History. See McBryde 1985.

7 For a valuable study of Barwick and her work, see Kijas 1992, 1993 and 1997. These discuss Barwick's role in the founding of Aboriginal History. However, Jo Kijas was handicapped by the fact that Barwick's voluminous papers, which include eight boxes of material relating to the journal, were unavailable at the time she conducted her research. She had to rely on the memory of key participants who had forgotten some of the critical moments in the journal's early years.

8 See, for example, Attwood 2005: 40.

9 Gunson 1959 and 1960-61; Gunson, 'My Personal Introduction to Aboriginal History', account prepared for the author, manuscript, 17 January 2012; Niel Gunson, interview with author, 18 
In 1962 Gunson returned to ANU to take up a research fellowship in the Department of Pacific History in the Research School of Pacific Studies. There he began work on two historical projects relating to Aboriginal people: a collection of historical sources pertaining to the missionary Lancelot Threlkeld, who had established an Aboriginal mission on Lake Macquarie in New South Wales in the mid 1820s; and a local history of Cranbourne (where he had spent his childhood) that would include a chapter about the Aboriginal people in the pre-colonial era as well as a couple of chapters about their relations with the European intruders in the first generation of contact. At the same time, Gunson helped to establish the National Aboriginal Day Observance Committee (NADOC) of the Australian Capital Territory (ACT) and assumed the role of its chairman. He saw NADOC as a body that attempted 'to do something about the apathy of the public in regard to the Aboriginal community', especially 'its rights, its problems and its cultural heritage'. The organisation's work included staging annual exhibitions of Aboriginal artefacts and paintings. ${ }^{10}$

At some point, the conjunction of Gunson's scholarly interests and humanitarian concerns led him to contemplate starting a journal focusing on the Aboriginal past. That he chose a periodical as the means to pursue his passions is probably unsurprising; he worked in a Department of Pacific History (created by the New Zealand historian JW Davidson) in which a journal devoted to the field of Pacific history had been launched in 1966. The Journal of Pacific History was to provide Gunson, who was involved in that enterprise from the outset, with a model, if not the model, for what became Aboriginal History. (The early 1970s also saw the founding of several journals devoted to South and Southeast Asian history, as scholars took a growing interest in decolonisation, and this might have exerted some influence on him as well.) However, precisely when and how Gunson decided to found a journal dedicated to the past of Australia's indigenous peoples is unclear. ${ }^{11}$ All we can know for sure is that it took several years before his idea came to fruition and that his proposal stalled at least once along the way. ${ }^{12}$

It seems that Gunson's idea of the journal arose most immediately out of his experience as Chairman of NADOC in the ACT in the late 1960s. He had hoped that the body would act as a co-ordinating body for all the organisations in the nation's capital that had an interest in Aboriginal people, especially the churches and service clubs. But by the end of 1968 he realised that the times

January 2012; Niel Gunson to author, 8 April 2012; <http://missionaries.griffith.edu.au/qldmission/zion-hill-mission-1838-1848> accessed 14 April 2012.

10 Gunson to the Executive of AIAS, 29 April 1964, Stanner Papers, Series 18, Item 19; Gunson, Script of Speech for General Meeting of NADOC ACT, 6 June 1967, NADOC ACT Chairman's Report 1968, 19 November 1968, Gunson Papers; Gunson 1968: xi-xii; Gunson 1974: vii; Gunson, interview with author, 18 January 2012; Gunson to author, 8 April 2012.

11 Two of Gunson's accounts of this, based on memory, are a matter of public record (Gunson 2000 and 2006). My account, based on a consideration of the documentary historical sources, his recollections (both public and private), and the contemporary historical context, differs from Gunson's on several key points.

12 Foster and Varghese 1996: 107; Gunson 2006: 72; Gunson, ‘My Personal Introduction to Aboriginal History'. 
were changing. The federal government, following the success the previous year of the referendum to alter two clauses of the Australian Constitution referring to Aboriginal people, had appointed a new advisory committee, the Council for Aboriginal Affairs; and Aboriginal leaders such as Charles Perkins and Kath Walker had begun to demand that Aboriginal people take charge of organisations that purported to represent Aborigines. It was evident to some white Australians at least that the days of white dominated organisations were over. 'The NADOC Committee felt it was better for Aboriginal people themselves to take a more active part in promoting their own culture', Gunson has recalled. In the early months of 1969 the ACT NADOC committee agreed that it should disband. In the wake of this, Gunson travelled to Sydney to seek the guidance of Perkins as to what he might do now to help Aboriginal people, though it seems that he had already decided that the best way he might continue to serve the Aboriginal cause was by doing what he knew best, namely history, or, more specifically, by founding a journal of Aboriginal history. ${ }^{13}$ A periodical of the kind he had in mind would, Gunson later remarked, 'instruct others about the history of the Aboriginal people, ... enabl[e] Aborigines to record their own history and give it a greater place in the national life' ${ }^{14}$

At this time, if not earlier, Gunson had a conversation with Peter Corris (1942- ) about his idea of a journal. ${ }^{15}$ Corris, before embarking on a PhD at ANU in 1967 on the labour trade in the Solomon Islands, had done research (for a Masters at Monash University) on the history of the first generation of contact between Aborigines and Europeans in the Western District of Victoria. This was one of the first studies of this kind and it became one of the first of a crop of books published on the subject. At much the same time Corris had penned a thoughtful consideration of recent scholarly work on the post-colonial Aboriginal past and recommended a series of research projects. In the light of all this it is not surprising that he was sympathetic to Gunson's proposal. However, it seems that Gunson's colleagues were not. They included WEH Stanner. In his Australian

13 In an appreciation Gunson wrote in 2000-01 after Perkins has passed away, he stated: 'I told [Perkins] that our NADOC committee was disbanding but that there was a lot of goodwill and that I would like to know what we could do to help the Aboriginal cause. After some discussion which provided no solution he suddenly said to my surprise 'You're a historian aren't you, do something about Aboriginal history' (2000: 258-259; see also Gunson 2006: 76). For two reasons I believe it would be a mistake to attribute too much significance to Perkins' remark. Gunson had already thought of starting a journal and the story he tells here seems to owe a good deal to the moment that prompted it (Gunson 2006: 259; Gunson to author, 17 April 2012 and 18 April 2012).

14 NADOC ACT Chairman's Report 1968, 19 November 1968, Gunson to Rev WS Pidgeon, 13 December 1968, Gunson to Chairman, Canberra Regional Board, Baptist Homes Trust, 29 July 1969, and Gunson, Script of Speech for the Launch of Vol. 5 of Aboriginal History, 8 July 1982, Gunson Papers; Attwood and Markus 1999: 239-241; Attwood 2003: 321; Gunson, 'My Personal Introduction to Aboriginal History'; Gunson, interview with author, 18 January 2012; Gunson to author, 8 March 2012, 12 March 2012, 8 April 2012, 17 April 2012 and 18 April 2012.

15 Gunson once claimed this conversation took place in the early to mid 1960s (Gunson 2000: 258), but he has recently conceded that this cannot be so (Gunson, personal communication, 17 January 2012) as the two men only met for the first time in 1967. Gunson kept diaries during this time which might help date this conversation, but these are unavailable at present and Corris has no recollection of their discussion (Gunson, personal communication, 17 January 2012; Gaby Naher to author, 25 January 2012). 
Broadcasting Commission Boyer Lectures of 1968 the renowned anthropologist had criticised what he called 'the great Australian silence' about the relationship between Aborigines and white Australians, chastised historians for their role in perpetuating it, recognised that there another 'side of the story' whose telling 'would have to be a world - [or] perhaps ... an underworld - away from the conventional histories of the coming and development of British civilisation' in Australia, suggested that it would 'cut like a knife' through much of what white Australians said and wrote, and argued that they would have to bring this material, which he self consciously called ethnohistory, 'into the sweep of our story'. Yet, according to Gunson, Stanner was opposed to a journal of the kind Gunson had in mind and told him that it would 'raise expectations in the community at large and eventually backfire against Aborigines who were not able to live up to these'. Senior historians at ANU were, Gunson remembers, similarly discouraging. This reflected a more general scepticism among academic historians about the worth of historical studies that focused on Aboriginal people. At this time the editor of Australia's premier academic journal in the field of Australian history, Historical Studies, is said to have told a young historian by the name of Henry Reynolds 'not to waste time on writing about Aborigines as there was nothing in it'. ${ }^{16}$

At this point Gunson seems to have set aside his idea of a journal. But in 1973 another historian interested in the history of relations between Aboriginal people and Europeans arrived in his department. Bob Reece (1942- ) had come to do a doctoral thesis on the cession of Sarawak (on the north-west coast of Borneo) to the British Crown at the end of World War Two. A few years earlier he had completed a major study of contact between Aborigines and Europeans in New South Wales in the 1830s and 1840s (for a Masters at the University of Queensland). It was, as I have already implied, unusual at this time for an academic historian to conduct such research. Reece met Gunson soon after he began his Masters thesis and had been excited to learn that there was at least someone who took a genuine interest in it, and in the next couple of years both Gunson and Corris read some of the chapters of his dissertation as it progressed. After Reece arrived at ANU he revised this thesis for publication as a monograph. In its preface, after observing that his research had been influenced by the fact that all the documentary sources available to him had been created by the settlers, Reece expressed regret that it had not been possible 'to say more about the Aborigines' perceptions of the whites' and suggested that this task would have to be undertaken by others. Yet his doctoral work had introduced him to a seminal essay by John RW Smail that urged historians of Southeast Asia to adopt approaches that would enable them to recover what this American scholar called the 'autonomous history' or the 'autonomous worlds' of local peoples, and this prompted Reece to ponder how the same might be done in the Australian context. In 1976, he would seek out contemporary Aboriginal perspectives of the past, travelling with the filmmakers David and Judith MacDougall to Moree

16 Corris 1966, 1968 and 1969; Stanner 1969: 22-25; Felton 1991: 32; Reynolds, cited Daly 1998; Gunson 2000: 258; Gunson 2006: 76; Gunson to author, 12 March 2012. 
in northern New South Wales in order to collect an oral tradition regarding the 1838 Myall Creek Massacre, and he would present a seminar paper at ANU on Aborigines in Australian historiography. But, before this happened, he and Gunson discussed the latter's proposal of a journal of Aboriginal history, and Gunson decided to revive it. ${ }^{17}$

By this time interest in undertaking research in the field had been sparked among a larger number of historians, and a shining example of what could be done had appeared. In 1970-71, Charles Rowley's three-volume history of Aboriginal policy and practice, The Destruction of Aboriginal Society, Outcasts in White Australia, and The Remote Aborigines, which had sprung from a Social Science Research Council project on Aboriginal welfare begun in 1964, had been published by the ANU Press. This landmark work, as historian Stuart Macintyre has reminded us recently, 'wrote Aborigines back into Australian history'. More particularly, it uncovered a rich lode of material buried in Australian libraries and provided the first systematic historical account of the destruction and dispossession of Aboriginal people. ${ }^{18}$

In September 1975 Gunson called a meeting to discuss the purpose of a journal of Aboriginal history, its viability, the formation of an editorial board, the make-up of a national committee (to serve as correspondents and consultants), the costs involved and the need for sponsors, though he had already ensured that there would be agreement on who would assume the journal's key positions. Gunson sought a wide base of support for the journal. He, Reece and Corris (in whose names the meeting was called) invited three other historians: Ann Curthoys (1945- ), Hank Nelson (1937-2012), and Charles Rowley (1906-85). Curthoys had completed a PhD thesis at Macquarie University two years previously in which she had compared the response of British settlers to Aborigines, Chinese, and non-British Europeans in New South Wales in the mid to late nineteenth century, and had recently been appointed to establish a Women's Studies programme in the School of General Studies at ANU, where she was housed in its Department of History. Nelson was one of their colleagues in the Department of Pacific and Southeast Asian History and a specialist on Papua New Guinea who had done a Masters thesis (at the University of Melbourne) on missionary attempts to civilise and christianise Aborigines in the Port Phillip District of New South Wales. And Rowley was the author of the recently published trilogy on the history of Aboriginal policy and practice. ${ }^{19}$

Gunson also invited two anthropologists and a prehistorian who he personally knew: Diane Barwick (1938-86), Nicolas Peterson (1941- ), and Isabel McBryde

17 Smail 1961; Bob Reece to Gunson, 14 February 1966, Gunson Papers; Reece 1969; Reece 1974: viii; Reece to Peter Corris, 24 June 1975, Reece Papers; MacDougall 1976; Reece 1976; Reece 1982; Sears 1993: 6-7; Gunson 2006: 76; Bob Reece to author, 8 and 9 February 2012.

18 Macintyre 2010: 156-157, 161, 163.

19 The Journal of Aboriginal History, Agenda for Foundation Board Policy Meeting on 4 September 1975, and The Journal of Aboriginal History: Scope and Management, undated, Barwick Papers, Box 2, BARI02404; Gunson and Reece, Circular letter, 11 November 1975; Curthoys 1973; Nelson 1966; Gunson to author, 8 March 2012. 
(1934- ). Barwick was a Canadian-born scholar who, since completing a PhD thesis in anthropology at ANU in 1963, had undertaken a good deal of historical research, largely during a term as a research fellow in the Department of Anthropology and Sociology in the Research School of Pacific Studies at the University (1966-72), which culminated in the completion of a draft book manuscript on the history of Coranderrk Aboriginal Reserve (50 kms north-east of Melbourne). Peterson, a research fellow in the Department of Anthropology and Sociology in the Research School of Pacific Studies at ANU, would have been seen by the journal's founders as an anthropologist who was currently working with Aboriginal people and he had recently undertaken some historical work as the Research Officer for the Commonwealth government's Aboriginal Land Rights Commission. (Very soon, an increasing number of anthropologists in Australia would become more historically minded as a consequence of the work they undertook on behalf of Aboriginal communities under the provisions of the Commonwealth's Northern Territory Land Rights Act 1976, which required claimants to provide evidence of their historical occupancy and use of the land. $)^{20}$ McBryde was a senior lecturer in the Department of Prehistory and Anthropology at ANU, who had, after taking her first degrees in Latin and History, trained as an archaeologist and undertaken pioneering ethnohistorical research about the Aboriginal people of New England in Northeastern New South Wales. And, shortly after the journal's first meeting, a linguist, Luise Hercus (1926- ), who had been appointed to teach Sanskrit in the Faculty of Asian Studies at ANU but who had also undertaken research salvaging Victorian Aboriginal languages that were on the brink of extinction, was invited to join the editorial board. As it turned out, the involvement of most of the historians named here, that is, Corris, Curthoys, Reece and Rowley, as well as nearly all of the historians who succeeded them on the editorial board, was to prove relatively short-lived..$^{21}$ It was the anthropologist Barwick, the prehistorian McBryde and the linguist Hercus who would join Gunson in becoming the journal's key figures. This outcome in terms of disciplinary representation was partly a consequence of the lowly status of the field among academic historians at this time. Very few tenured positions were on offer at ANU for those working on 'Aboriginal history' and so they had to depart for university posts elsewhere. ${ }^{22}$

The inaugural meeting did much to establish the nature of the journal, which was going to be known as The Journal of Aboriginal History. Those attending

20 This growing interest in history among Australian anthropologists paralleled the importance that history had come to have among North American anthropologists several decades earlier in the context of their work for the Indian Claims Commission, which had played a major role in the foundation of the new sub-discipline of ethnohistory (see McMillen 2007 and Harkin 2010).

21 In these early years several historians served for varying lengths of time: Andrew Markus, Lyndall Ryan, Peter Biskup, Kerry Howe and, most importantly, Stephen Foster, who became the chairman of the editorial board for the period 1985-88. Nelson was a member of the board for a lengthy period but, while he made an important contribution at times, his involvement was spasmodic (Minutes of Aboriginal History Editorial Board Meeting, 28 November 1986, Gunson Papers).

22 Barwick 1963; McBryde 1966, 1974 and 1978; Hercus 1969; Peterson 2006: 32-33; Luise Hercus, interview with author, 18 January 2012; Gunson, interview with author, 18 January 2012; Gunson to author, 8 March 2012. 
seemed to agree on most matters, though there was a degree of ambiguity surrounding some important questions, as we will see later. Most importantly, they felt that the journal should try to nurture a historical enterprise that would depart from many of the conventions that had long dominated the discipline of history in European countries. This had several dimensions. First, what the journal's planners described as both 'the field of Aboriginal history' and 'the field of Australian ethnohistory' would expand the temporal sense of history in that it would focus not only on the time that had traditionally concerned historians of Australia, namely the era since British settlement commenced in 1788, but also the pre-colonial period that had long been held by Anglo-Celtic Australians to be the preserve of the disciplines of anthropology, archaeology and linguistics. 'While it will be concerned principally with articles relating to the post-European contact history of the Aboriginal people, it will also publish articles of a historical nature in fields such as anthropology, prehistory, linguistics and sociology', the journal's planners stated. Perhaps realising that this was ambiguous, they added: 'Thus an article on traditional [i.e. pre-colonial] trade routes reconstructed from prehistory and oral sources would be welcome'. As it turned out, the journal was to publish little work of this kind (much to Gunson's regret). Its interest in such research was criticised by the eminent anthropologist AP Elkin, who was the founder and long-time editor of the anthropological journal Oceania. He was probably keen to ensure that his discipline maintained its dominance in the field of Aboriginal Studies. 'I don't think the journal should stray into the fields [covered by] of anthropology, prehistory, linguistics, etc', he told Reece. 'After all, there are journals and monographs and so on to deal with such topics.' Second, those taking the lead in planning the journal presumed it would concentrate largely on Aboriginal people; that is, Aborigines would be the primary subject and subjects of the past under consideration. This said, the founders of the journal were of a mind that the journal should include work on other non-European minority groups such as Afghans and Chinese. ${ }^{23}$ But it seems that they chose The Journal of Aboriginal History as the periodical's name in order to distinguish the journal - and in turn define 'Aboriginal history' - as a historical endeavour that would or should have a different set of priorities from the field of Australian history. ${ }^{24}$

One of those who grasped the latter point was opposed to the journal's undertaking. Sir Paul Hasluck had been Minister for the Territories in the Menzies Government between 1951 and 1963 with special responsibility for Aboriginal affairs (and most recently Australia's Governor-General), and he had previously authored a scholarly history of relations between Aborigines and Europeans. He was one of a number of figures in the field of Aboriginal Studies whom Gunson and Reece approached to seek their opinion about their proposal or to get their endorsement of it. 'After the coming of the Europeans', Hasluck was to tell

23 Gunson and Reece might have been dissuaded from pursuing this after Elkin pointed out that the Australian Institute of Aboriginal Studies would be unwilling to provide any subsidy for the publication of articles of this nature (AP Elkin to Reece, 27 October 1975, Gunson Papers).

24 Gunson and Reece, Circular letter, 11 November 1975; Elkin to Reece, 27 October 1975; Gunson, interview with author, 18 January 2012. 
Gunson, 'I find difficulty in separating the idea of the history of aborigines, or the idea of the history of the Europeans from the more comprehensive concept of the history of Australia. I also wonder whether historical truth may suffer if a history of aborigines is put in a separate compartment from the history of the Australian people'. Hasluck's concerns were not solely intellectual ones. He was apprehensive that the journal was a venture that was contrary to the policy of assimilation he had championed during his years in office. '[T]he social and political development of Australia', he warned Gunson, 'may suffer if persons looking at the history of Australian development in the broadest national sense continue to either exclude aborigines from the general view or minimise their place in it, or to regard them as being something apart from the rest of life in Australia'. More especially, Hasluck was suspicious that the conception of the journal was informed by what he saw as a contemporary tendency to favour 'a policy of "separate development"'. He concluded: 'I find myself in full sympathy with your project so far as it is concerned with gathering information which will bring a clearer insight into the pre-history of Australia, the language, traditions and customs of the aboriginal people, and the social and cultural consequences of European settlement, but I am out of sympathy with the idea of "aboriginal history" as a distinct and separate field of historical studies in Australia'. ${ }^{25}$

In replying to this criticism Gunson set out what he saw as the journal's project: 'I certainly respect the view that the Aboriginal people should be thought of simply as Australians and consequently the subject of Australian history. Nevertheless, I believe that it is time to present an Aboriginal perspective which would illuminate much of Australia's past and balance the European oriented history of our country'. Presenting Aboriginal people's perspectives or points of view both in the past and of the past would become fundamental to the way in which most, though by no means all, of the journal's editorial board regarded the work of the periodical. In describing the journal's enterprise to Hasluck, Gunson similarly made it clear that he hoped the journal would do more than simply publish work concerned with Australia's dark colonial past. 'I would be distressed if all our contributors concentrated on themes of social injustice', he told Hasluck, 'but only because I believe that this would not reflect the whole picture of Aboriginal-European relations'. This point was critical to the kind of journal Gunson and his fellow planners had in mind. Their concerns were broader than, or even different to, those historians who sought to represent those relations primarily in terms of the exclusion, exploitation and extermination of Aboriginal people (to use the terms of a book that had been published recently). In concluding his reply to Hasluck, Gunson remarked: 'My own personal concern is to present an accurate account of the past in an age when activists of different persuasions are only too eager to argue that what people think happened in the past is more important politically and socially than what actually happened'. This was no mere window dressing. Accounts of Australia's past were becoming increasingly important because the nature of the political claims being advanced at this time, most especially 'land rights', were fundamentally historical in the

25 Hasluck 1942; Sir Paul Hasluck to Gunson, 6 November 1975, Gunson Papers. 
sense that they were grounded in the past or at least representations of the past. In this context Gunson was committed to a position that scholarly work could be relatively objective and that this endeavour should be to the fore. ${ }^{26}$

In keeping with the premise that the principal historical subject and subjects of 'Aboriginal history' would be Aboriginal people, the journal's planners envisaged that it would pay considerable attention to the role that the culture of the Aboriginal people had played in shaping their post-contact history. For those working in the field of Pacific history the adoption of this approach was axiomatic. JW Davidson and his acolytes not only had a conviction that the history of contact between Europeans and non-Europeans in the Pacific could only be properly understood by historians broadening their conceptual framework so they considered and analysed both sides or both points of view; they also believed that the response of indigenous peoples to European intruders had been largely determined by the pattern of their own cultures. In accordance with this approach, the planners of the journal stated: 'The basic concern of the Journal will be the writing of inter-cultural history, i.e. where possible, authors will be expected to analyse historical situations by examining the sources of the two or more cultures involved'. This in turn had significant implications for the nature of historical practice. As in the case of the practitioners of Pacific history and ethnohistory more generally, the horizons of the discipline of history had to be expanded so that its resources included non-European material and its conceptual frameworks drew upon those used in other disciplines. 'Thus', Gunson and Reece stated, 'considerable importance will be given to oral tradition [and] vernacular records, and the insights of prehistory, anthropology, etc'. (During this period, historians of European societies were increasingly drawing on concepts and methods they gleaned from the work of cultural anthropologists such as Victor Turner, Mary Douglas and Clifford Geertz.) The Australian anthropologist Jeremy Beckett, who was among the scholars Gunson and Reece approached for support, welcomed the proposal to include oral tradition and urged the journal's promoters to 'include other material that expresse[d] Aboriginal perceptions'. Prehistorians, most notably Isabel McBryde and John Mulvaney, advocated much the same kind of approach and called upon historians to look beyond the written word, especially by considering the material record of the past. ${ }^{27}$

Yet there is a sense in which the planners of the journal had a traditional conception of their enterprise and thus what 'Aboriginal history' would mean. The naming of their enterprise The Journal of Aboriginal History might suggest that its promoters had both the principal meanings of the term 'history' equally in mind; that is, that they wished to reveal the myriad ways the past could be represented as much as they wished to uncover what actually happened in the past. However, while it is clear that they wanted to include material that would, in their words, 'illustrate Aboriginal perceptions of the past', it is apparent that

26 Evans et al 1975; Gunson to Hasluck, 13 January 1976, Gunson Papers.

27 Davidson 1966: 5, 8-10, 13; Mulvaney 1969; McBryde 1974; Beckett to Gunson and Reece, 18 October 1975, Gunson Papers; Gunson and Reece, Circular letter, 11 November 1975. 
they regarded Aboriginal oral traditions, vernacular writings and the like as sources for the writing of Aboriginal history rather than sources of Aboriginal history or as histories in their own right. Thus, they were planning to distinguish between articles, reviews and review articles (of the kind usually accepted by learned journals) on the one hand, and notes and documents (which would include unpublished manuscripts, oral traditions and the like) on the other, and in fact this division was adopted in the early volumes of the journal, with the latter printed in a smaller font than the former. ${ }^{28}$ In making this distinction, the journal's promoters were following the way in which The Journal of Pacific History conceptualised its content. ${ }^{29}$

In terms of audience the journal's planners envisaged a much broader readership than most academic periodicals usually seek. There were at least two reasons for this. First, they believed that the periodical should strive to cater for the needs of Aboriginal readers. 'The stage is being reached when many Aboriginals are asking questions about the past and it is important that there should be available a body of scholarly writing for their reference and use', Gunson and Reece argued. It might be contended that their premise was a paternalistic one in the sense that they assumed that Aboriginal people needed guidance and that nonAboriginal scholars were able to provide this. Yet it can be argued that this goal reflected a real need. As Charles Rowley had observed in the opening chapter of The Destruction of Aboriginal Society, both Aboriginal and white organisations pressing for reforms in Aboriginal affairs repeatedly made reference to the way Aboriginal people had been treated in the past but the impact of their arguments was 'diminished by the lack of a common fund of historical knowledge'. Second, they were aware of what they described as 'increasing public interest in Aboriginal history' in both schools and the media, and consequently they hoped that the journal would gain a wider readership than most scholarly journals and thereby 'serve a valuable social function'. This approach reflected the dual reasons (the scholarly and the political) the journal had been created. In keeping with this reason it was hoped that the periodical would seek to avoid professional jargon, have a greater preoccupation with good writing than was usual in an academic journal, and include illustrations and an attractive looking cover (in the manner of the British magazine History Today). ${ }^{30}$

28 In due course this distinction was the subject of some disagreement between members of the editorial board. Indeed, as early as April 1978, the minutes of a board meeting recorded: 'As usual there was the problem of deciding if articles were appropriate for part 1 or 2 . Documentary type articles and archival material would automatically go into part 2 but other vernacular or oral history type articles about which there was some doubt would just have to be looked at individually and a decision made' (Gunson to Reece, undated [c. March-April 1977], Minutes of Aboriginal History Editorial Board Meeting, 10 February 1978, and Minutes of Aboriginal History Editorial Board Meeting, 14 April 1977 [sic, 1978], Gunson Papers).

29 Gunson and Reece, Circular letter, 11 November 1975; document, undated [c. October 1975], Barwick Papers, Box 2, BARI02404; Barwick to Peter Grimshaw, 22 February 1979, Barwick Papers, Box 2, BARI02408.

30 Rowley 1970a: 8; Gunson and Reece, Circular letter, 11 November 1975; Gunson to Anthony Forge, 14 January 1975 [sic, 1976], Barwick Papers, Box 1, BARI02404. 
The planners of the journal assumed it would be an occasional publication, though preferably one that appeared annually. They had good reason to be cautious. John Mulvaney, for one, had doubted there were enough scholars working in the field to make the journal viable. However, Gunson and Reece believed that there were a growing number of scholars doing research in the area, and assumed that the journal would both attract material that authors currently placed in more general historical journals but where it tended to be submerged, and stimulate further research in the field. ${ }^{31}$

The journal's inaugural meeting decided that it would be overseen by an editorial board based in Canberra, and that its members would play a major role in its production by performing much of the work of refereeing. This policy, which became the journal's practice, could not have been adopted in any other place in Australia. As the roll-call at the journal's first meeting has revealed, there was a critical mass of scholars at ANU who were working or had worked in the field of 'Aboriginal history' and whose advice and input could be drawn upon. To their names several more could be added, such as the prehistorians Jack Golson, Rhys Jones and Mulvaney, ${ }^{32}$ the archaeologist and historian Campbell MacKnight, the demographer FL Jones, the anthropologists Marie Reay and WEH Stanner, and the linguist RMW Dixon. The discipline of prehistory was especially important. Mulvaney and McBryde's vision of it as an area of study that sought to provide an integrated study of the past by drawing on disciplines like archaeology, anthropology, geomorphology and history provided something of a model for the work the journal would encourage. And, as the editorial board was to learn in due course, they could rely on the moral support of the historian Ken Inglis, Professor of History in the Research School of Social Sciences. He had recently observed the burgeoning of indigenous history at the University of Papua New Guinea while he was professor of history and later Vice-Chancellor; he had previously authored a book about the controversial case of an Aboriginal man convicted of murdering an eight-year-old girl in South Australia; and he had been married to Judy Inglis, an anthropologist working among Aboriginal people in South Australia who had a similarly historical approach to Barwick's and whose interest in the past and its impact on the present can be said to have played a part in laying some of the groundwork for the emergence of Aboriginal history as a field before she tragically died in $1962 .{ }^{33}$ At the same time, it might be argued that the unconventional nature of the Institute of Advanced Studies at ANU encouraged an inter-disciplinary venture of this kind: the disciplines were located in multi-disciplinary research schools, rather than single-discipline departments, and the Research School of Social Sciences and the Research School of Pacific Studies were both housed in the Coombs Building, where members of staff gathered together regularly over morning and afternoon tea. ${ }^{34}$

31 Reece to Corris, 24 June 1975; Corris to Gunson, 12 October [1975], Gunson Papers; document, undated [c. October 1975]; Gunson and Reece, Circular letter, 11 November 1975.

32 Although Mulvaney was first sceptical about the viability of the venture, he soon backed it (Reece to Corris, 24 June 1975; cf Kijas 1993: 86-87).

33 For a discussion of Inglis' work, see Kerin 2007.

34 Gunson and Reece, Circular letter, 11 November 1975; Ken Inglis to Gunson, 4 May [1978], Gunson Papers; Minutes of Aboriginal History Editorial Board Meeting, 5 May 1978, Barwick Papers, Box 1, BARI02274; Inglis to Dorothy Green, 6 December 1978, Barwick Papers, Box 2, 
Like any journal, Aboriginal History had to find a source of money to meet, at the very least, the cost of publication. Gunson and Reece seem to have assumed that the novel historical nature of their project meant that they would be unable to win any funding from ANU. They proposed to seek funding from several public sources instead, which included the Department of Aboriginal Affairs, the Literature Board of the Australia Council for the Arts, and the Aboriginal Arts Board. Their first port of call, however, was the Australian Institute of Aboriginal Studies, a body the federal government had established in 1964 in order to advance the study of Aboriginal culture. In October and November 1975 Gunson and Reece put a proposal to its Publications Committee that included a suggestion that the journal become the Institute's publication, ${ }^{35}$ though the journal's editorial board would determine and oversee the material submitted to it. After some consideration, the Institute, which continued to be dominated by the discipline of anthropology, rejected the proposal. At this point Gunson and Reece approached HC (Nugget) Coombs, the senior Commonwealth public servant who until recently had been Chairman of the federal government's small advisory body the Council for Aboriginal Affairs as well as Chairman of the Australian Council for the Arts, but he no longer held any governmental position and was unable to help. For several months it looked as though the venture might falter. Although Gunson reconvened the editorial board in the closing months of 1976 and planning for the first volume resumed, by year's end the journal had still not secured any funding. ${ }^{36}$

At this point Gunson seems to have turned to Peter Grimshaw (1932-2003), the Business Manager for both the Research School of Pacific Studies and the Research School of Social Sciences. (He would play a valuable role in the journal's affairs after Gunson invited him to be its treasurer and its public officer. ${ }^{37}$ Grimshaw in turn made an approach to the Director of the Research School of Pacific Studies, Professor Wang Gungwu, explaining that the journal would have two aims: 'it would serve as a vehicle of communication for scholarly work on Aboriginal history, [and] provide a source of reference for Australians (both white and black) to become better acquainted with Aboriginal history'. Grimshaw was a skilled

BARI02407; Barwick to Tom Stannage, 20 March 1979, and Inglis to Barwick and Stannage, 6 August 1979, Barwick Papers, Box 3, BARI02427; Foster and Varghese 1996: 240-242; Kerin 2007: 439; Mulvaney 2011: 332.

35 In 1983 the Institute began publishing its own journal, Australian Aboriginal Studies, which had a broader focus and a more popular approach than that of Aboriginal History.

36 Shirley Andrew, Editor of Publications, Australian Institute of Aboriginal Studies, to Gunson, 27 October 1975, Gunson and Reece to Andrew, 10 November 1975, and Forge to Gunson, 18 December 1975, Gunson Papers; Gunson and Reece, Circular letter, 11 November 1975; Minutes of AIAS Publications Committee Meeting, 14 December 1975, AIATSIS Records, File Z73/7-3, Part 3; Gunson to Forge, 14 January 1975 [sic, 1976]; Minutes of AIAS Publications Committee Meeting, 5 March 1976 and 25 June 1976, AIATSIS Records, File Z73/7-3, Part 4; Forge to Gunson, 26 March 1976, HC Coombs to Gunson and Reece, 5 April 1976, and Gunson to Wang, 21 December 1976, Gunson Papers; Reece to Beckett, 2 April 1976; Curthoys to Gunson, 3 November 1976, and Markus to Gunson, 4 November 1976, Gunson Papers; Rowse 2000: 174.

37 Gunson has recalled that Grimshaw had a strong feeling for the cause of indigenous people largely born of the fact that he had spent his early years in Papua New Guinea (2003: 245246). But perhaps the principal reason for Grimshaw's invaluable support was that he was the quintessential patron who loved to see money being used to advance good causes (Stephen Foster to author, 5 March 2012; Tom Stannage to author, 8 March 2012). 
academic operator. He knew how to make a pitch. 'In considering [the latter aim] in its proper perspective', Grimshaw suggested, 'one could almost be forgiven for forming the conclusion that the need for such a journal is of national importance. If our First Australians require such a journal to learn a little about their own history then the need assumes such a degree of importance'. Wang, a historian of China who had previously held the chair of Far Eastern History in the Research School of Pacific Studies, was sympathetic to the idea of a journal of the kind Gunson and Reece were proposing. Nevertheless, he was cautious. According to a recent account by Gunson, Wang had been involved in a similar kind of venture at the University of Malaya in Singapore that had been taken over by political interests. Certainly Wang wished to clarify the institutional arrangements Gunson and Reece had in mind for the journal they were planning. 'Is it to be an ANU journal? A department journal? Or is it to be an independent journal?', he wished to know. In the new year Gunson advised Wang that it would be an independent one. In the meantime, Grimshaw had found a source of funds that Wang could draw upon to support the venture with a one-off grant. The Research School of Pacific Studies had been receiving grants from the Ford Foundation (whose founding charter stated that its resources should be used 'for scientific, educational and charitable purposes' to advance 'public welfare'). Grimshaw had been investing these funds wisely, they had accrued several thousands of dollars in interest, and there were no restrictions on their use. Why not allocate the journal \$2000 from this little nest egg, Grimshaw suggested. Wang happily agreed. ${ }^{38}$

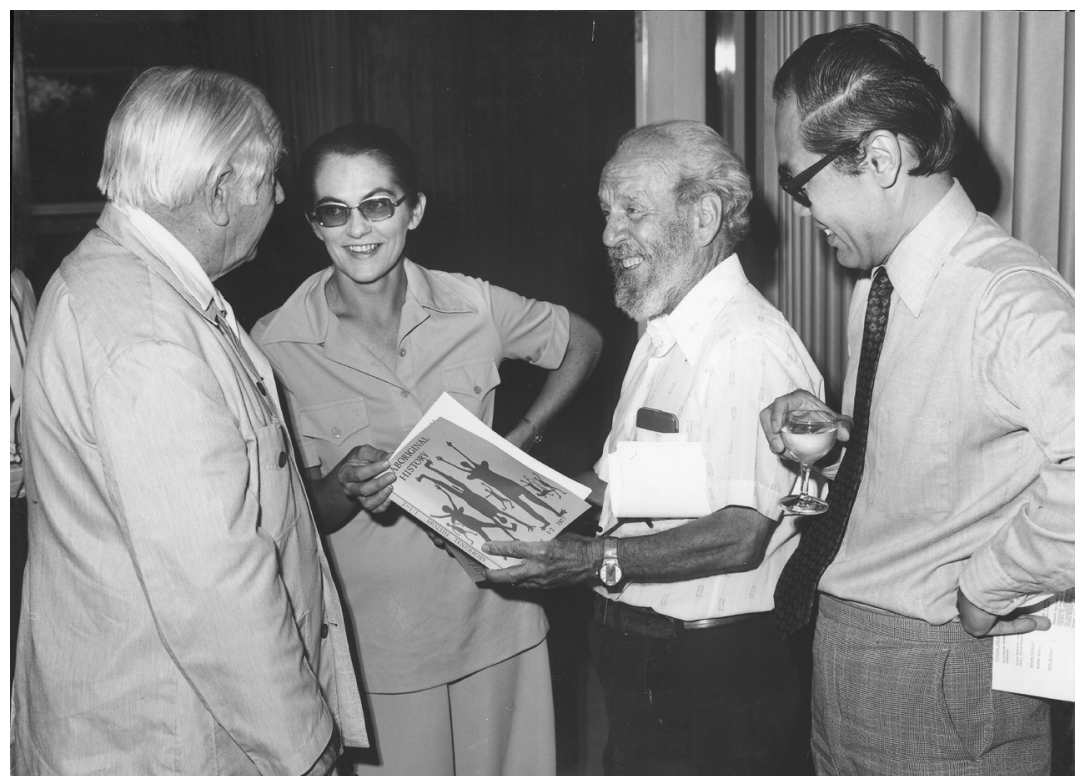

Illustration 1: From left to right: WEH Stanner, Diane Barwick, Nugget Coombs and Wang Gungwu at the launch of Volume 1 of the journal.

Source: University Archives, The Australian National University: ANUA225-1173-3.

38 Grimshaw to Wang, 13 December 1976, Gunson to Wang, 21 December 1976, Wang to Gunson, 21 December 1976, Gunson to Wang, 16 March 1977 and a minute on this by Wang, 22 March 1977, Gunson Papers; <http:/ / www.fordfoundation.org/about-us/history> accessed 25 January 2012; Gunson 2003: 245. 
However, by this time, March 1977, the journal needed more money as the ANU Printery had increased its quote for the first volume. Subsequently the journal's planners decided they should approach the Australian Institute of Aboriginal Studies once more. Fortunately, its Publications Committee happened to have a small amount of money left over in its budget and the Institute's Principal, Peter Ucko, agreed to grant the sum of $\$ 500$. The Journal of Aboriginal History was, finally, in business. ${ }^{39}$

At this stage the journal's editorial board had chosen most of the articles for the first volume but it was by no means clear who the executive editor or editors would be. According to Gunson's accounts of this matter, which rely on memory, Barwick was anointed as one of the journal's foundation editors at the moment of the journal's founding. The documentary record suggests otherwise. In the early stages of planning Barwick's name was never mentioned as a potential editor and it seems evident that the journal's founders were of the opinion that its editors should be professional historians. But by the early months of 1977 a change in personal circumstances had necessitated an alteration in these plans. Corris, having returned to the Research School of Pacific Studies at ANU to assume a research fellowship in 1971, had departed for a university post elsewhere and would soon choose to leave academic life to embark on a career as a literary journalist and a novelist; and Reece, having submitted his PhD and moved to Sydney to take up a temporary position with the New South Wales Education Department, was unable to take responsibility for steering the journal's first volume through to publication. (For his part Gunson had decided that, rather than be one of the journal's principal editors, it would be better if he were to perform the role of the chairman of the board that he had been playing from the outset, all the more so as he was committed to being the joint editor as well as the manuscripts editor of the Journal of Pacific History.) These changes presented the journal's planners with something of a quandary. In early March, Diane Barwick told Ann Curthoys: 'I don't think the projected Journal of Aboriginal History has an editor, although last week Niel was talking as if he thought Lyndall [Ryan] or I ought to feel called to higher service'. She added: 'I'm merely one of the ad hoc committee Niel assembled'. Yet Barwick had already begun to play an important role. A few months earlier, as Reece and Gunson were trying to meet proofreading deadlines, she had agreed to negotiate which papers would appear in the first volume, and it must have become apparent that she had the energy, the drive, the time and the skill to be the journal's principal editor or at least one of its editors. As a result of all these factors, it appears that sometime in the next few months the journal's board agreed that Barwick and Reece should be the co-editors of the first volume; that Gunson would take care of documents; and that Andrew Markus (1948- ), a historian appointed to a tutorship in the Department of History in the School of General Studies at the beginning of 1974, would replace Corris as review editor (after being invited by Reece to join the editorial board in November the previous year). ${ }^{40}$

39 Note for Meeting, 24 March 1977, Grimshaw to Gunson, 25 March 1977, Gunson to Peter Ucko, 28 March 1977, and Ucko to Gunson, 19 April 1977, Gunson Papers; Barwick to Reece, 19 October 1977, Barwick Papers, Box 1, BARI02403.

40 Reece to Corris, 24 June 1975; undated document, [c. October 1975]; Gunson and Reece, Circular letter, 11 November 1975; Markus to Gunson, 4 November 1976; Barwick, Diary, 28 February 1977, and Barwick, Daily Notebook, 8 March 1977, Barwick Papers, Series 9, Box 1, BARI00280; Barwick to Ann Curthoys, undated [8 March 1977], Gunson Papers; Gunson to Wang, 16 March 


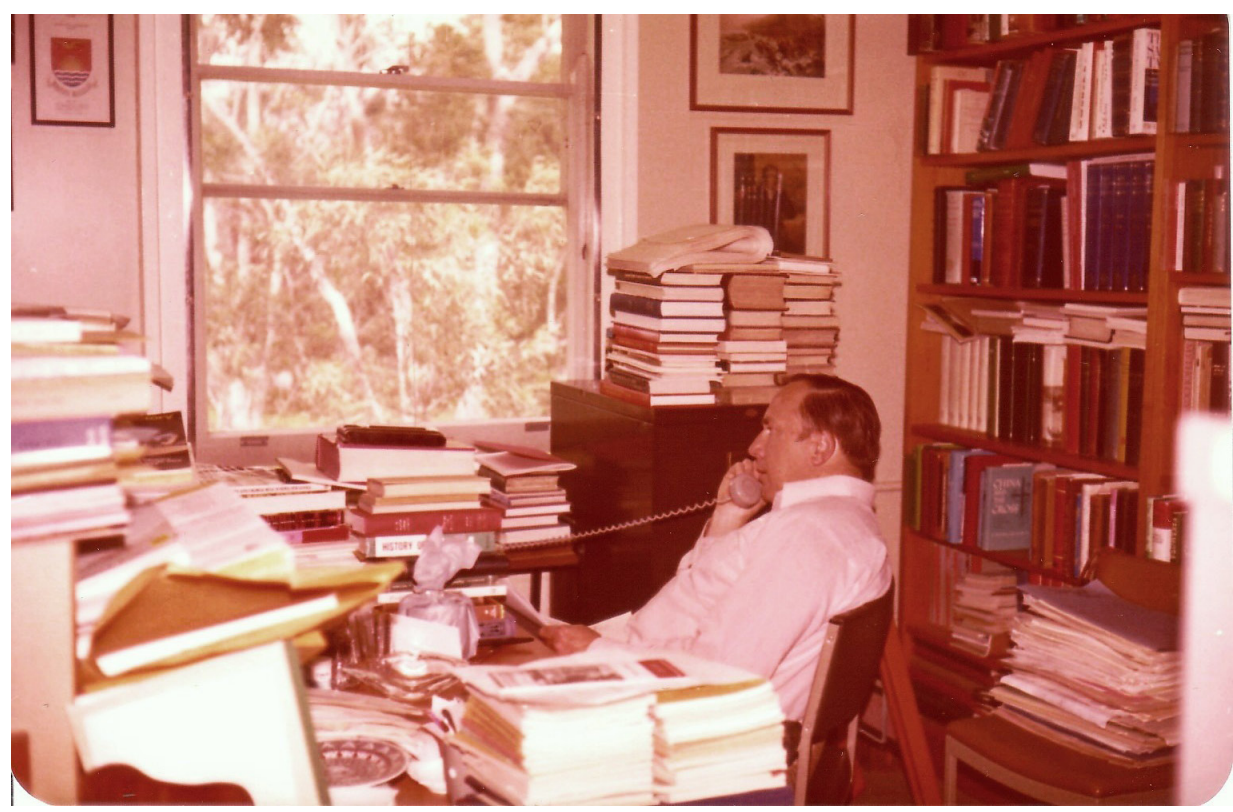

Illustration 2: Niel Gunson at work in his office in the Coombs Building at ANU in 1977.

Source: Niel Gunson Personal Collection.

As it turned out, Barwick would become the senior editor of the journal for the next five years. For much of that time, she was assisted by a succession of coeditors: in 1977 by Reece, in 1979 and 1980 by Tom Stannage (1944-2012), and between 1980 and 1982 by James Urry (1949- ). Stannage was a historian who had recently completed a history of Perth that devoted some attention to the history of Aboriginal people in that city, whose teaching of Australian history at the University of Western Australia had encompassed Aboriginal-European relations, and who held a research fellowship in the Department of History at the Research School of Social Sciences during the time he was co-editor. Urry was an anthropologist with a background in archaeology and history who worked as a bibliographer at the Australian Institute of Aboriginal Studies on his arrival in Australia (after undertaking doctoral studies in anthropology and history at Oxford University) before taking up a senior tutorship in the Department of Prehistory and Anthropology in the School of General Studies at ANU. These two men made important contributions to the journal but Barwick was the principal figure. ${ }^{41}$

1977; Reece to Gunson, 18 April 1977, Gunson Papers; Barwick to Reece, 19 October 1977; Gunson 1985: 4; Gunson to Stephen Foster, 15 April 1986, Gunson Papers; Gunson 2000: 259; Corris 2000: 104-105; Gunson 2006: 76-77; Reece to author, 20 January 2012; Markus to author, 28 February 2012; Gunson to author, 8 March 2012.

41 The Journal of Aboriginal History: Scope and Management; Agenda for Aboriginal History Meeting of 25 November 1977, 17 November 1977, Barwick Papers, Box 1, BARI02403; Minutes of Aboriginal History Editorial Board Meeting, 13 October 1978, Barwick Papers, Box 2, BARI02408; Gunson to Corris, 28 April 1978, Gunson Papers; Stannage 1979; Minutes of Aboriginal History Editorial Board Meeting, 20 July 1979, Barwick Papers, Box 1, BARI02275; Constitution of 
During these early years of the journal Gunson provided a home for it in the Department of Pacific and Southeast Asian History and anchored its affairs. As I have noted, he had his own sense of what the journal should become, but he also welcomed younger scholars onto its editorial board and was willing to allow those such as Barwick to pursue their own particular conception of the venture. He had an easy going personality and did his best to ensure that the journal's monthly lunchtime board meetings were friendly and civilised affairs. Most importantly, he was to wisely steer the ship through some troubled waters. ${ }^{42}$

\section{Defining and debating the nature of Aboriginal history}

While the editorial positions on the journal were being worked out, the periodical continued to be known as The Journal of Aboriginal History. However, at some point in the later months of 1977, its name was altered though it is not altogether clear why this occurred. According to Barwick, there was some apprehension that the subscriptions for a Journal of Aboriginal History would be muddled with those for the Journal of Pacific History since they had the same postal address. But perhaps the journal's key figures realised that the name Aboriginal History could help them to better articulate a particular orientation for the enterprise by placing an emphasis not only on Aboriginal people as subjects and actors but Aboriginal perceptions and perspectives as well. ${ }^{43}$

Barwick was particularly important in this regard. Nonetheless she was apparently diffident when Gunson first approached her about the journal. 'I had struck this kind of hesitancy before, particularly by senior anthropologists only too well aware that failure of an Aboriginal-oriented venture tended to reflect adversely on the Aboriginal people rather than on those organising the project', he has recalled. 'Expectations, I was told, were raised and could not be lived up to.' However, Barwick's reservations about the journal proved short-lived. She soon threw herself into the work. There are probably several reasons why this occurred. Barwick had a passionate intellectual, moral and political commitment to recovering the past of Aboriginal people, especially from their perspective, and to trying to spread knowledge of this as widely as possible. Furthermore, she relished the opportunity to work in a collective enterprise, particularly one in which a large number of supportive women were involved, most of all Isabel McBryde, Luise Hercus and, for a shorter period, Diane Bell. Barwick was reluctant to interpret the world in terms of gender, yet women played a major role in the journal's work, and their research appeared in its pages more often than it did in the traditional journals, which continued to be largely the preserve

Aboriginal History Inc, section 5(2), Gunson Papers; Aboriginal History, Chairman's Report for 1982-83, 18 March 1983, Barwick Papers, Box 1, BARI00136; Gunson 2006: 77; James Urry to author, 30 January 2012; Stannage to author, 8 March 2012.

42 Urry to author, 14 February 2012; Markus to author, 28 February 2012; Stannage to author, 8 March 2012.

43 Contents of Vol. 1, Draft Flyer, undated, Gunson Papers; Barwick to Grimshaw, 22 February 1979; Gunson, interview with author, 18 January 2012. 
of men who dominated the Australian academy. There is a sense, too, in which Barwick both wanted and needed a vehicle like the journal. She often felt herself to be a marginal figure in the academy, the discipline in which she had been trained (for reasons that will be discussed shortly), and a university in which a patriarchal hierarchy could determine the future of its teachers and researchers. Moreover, after her research fellowship in the Research School of Pacific Studies came to an end and she had a child, Barwick only had intermittent academic employment. In contrast, being editor of Aboriginal History, though it gave her neither a room nor any remuneration, provided her with some kind of status and authority. ${ }^{44}$

Barwick's appointment (if that is the right word) as one of the editors for the first number of the journal was to prove crucial to its direction. She made the enterprise her own and became the dominant force in its production. As we have observed, the nature of the journal had been carefully defined during or even before its first meeting, but Barwick would both sharpen and deepen particular aspects of the enterprise. This was so because in its early years she solicited much of the material that was submitted, played a major role in choosing what was accepted, and reshaped many of the papers.

Barwick's training had given her a particular intellectual orientation. As an Honours student at the University of British Columbia, where she was supervised by Harry Hawthorn, and as a curatorial assistant at the Provincial Museum of Natural History and Anthropology, Victoria, where she was guided by Wilson Duff, she had acquired a training in anthropological research that paid a good deal of attention to the role that the past played in the culture of the contemporary indigenous peoples of the area as well as their special status as its first occupants. This historical mindedness was in stark contrast to the approach that dominated Australian anthropology. Nearly all Australian anthropologists worked on so-called traditional Aboriginal communities in areas remote from cities and towns in southeastern Australia, and they paid scant regard in their anthropological writings to the historical changes these people had undergone as a consequence of contact with non-Aboriginal peoples. Furthermore, they directed their $\mathrm{PhD}$ students to do the same. But for her doctoral research Barwick undertook a study of 'part-Aborigines' in Melbourne and she paid considerable attention to the role that historical factors had played in producing what contemporary anthropology claimed these people no longer had, namely a distinctive Aboriginal culture. In other words, much about Barwick's work was doubly unfashionable. At this time, and, indeed, for many years to come, few anthropologists in the Aboriginal area conducted fieldwork among 'partAborigines' in 'settled Australia' or provided any historical treatment of Aboriginal communities in their anthropological studies. (Those like Jeremy Beckett, who sought to straddle the disciplines of anthropology and history and who befriended Barwick soon after her arrival in Australia, were unusual.)

44 Reece 1986a; Gunson to Foster, 15 April 1986; Bell 1986; Williams 1986: 1-3; Rowse 2007; Gunson, interview with author, 18 January 2012; Reece to author, 21 January 2012; Urry to author, 14 February 2012; Marian Quartly to author, 16 February 2012; Stannage to author, 8 March 2012. 
Furthermore, Barwick's approach was different in that she privileged the role of ethnography rather than the more conceptual work traditionally emphasised by many in her discipline. ${ }^{45}$

In the several years following the award of her PhD in 1964 Barwick began to combine the insights she had drawn from the ethnographic field work she had conducted among the Aboriginal community in Melbourne with the knowledge she was gleaning about these people from documentary research she carried out in the government archives. By the mid 1970s, if not earlier, she had become committed to trying to understand the lives of Aboriginal people, past and present, by adopting an approach that drew upon both ethnographic and historical approaches. This in turn prompted her to consider what the field of Aboriginal history could or should be. During the journal's early years, Barwick never explicated her concept of Aboriginal history in any thorough way (just as the journal's promoters were reluctant to make more than a brief statement in its first volume). ${ }^{46}$ Yet the kind of journal she had in mind and pursued is evident in letters she wrote to contributors to the journal as well as to her fellow editors and members of the editorial board, and in the content of the early volumes of the journal.

Barwick, and those closest to her on the editorial board, namely Hercus and McBryde, were determined that Aboriginal history would focus on Aboriginal people. This had, at the very least, two, inter-related dimensions. First, Aborigines rather than anyone else were to be its principal subjects. At the launch of the journal's first volume, Barwick stated that its task was to bring about a new kind of Australian historical writing by 'put[ting] Aborigines in focus instead of in the footnotes'. What she meant was not altogether clear, but a few years later she spelt this out when she insisted that 'innovations in language and kinship systems, economic adaptations, migration, trade and exchange, the spread of ceremonies, and other changes within Aboriginal society [were] as important to Aboriginal history as the changes imposed by European control'. This is to say that Barwick prescribed the undertaking of what might be called an internal history. This made clear that the project of Aboriginal history was to be different from that of the history of colonialism as its primary subjects were to be the indigenous peoples, and developments among them, rather than the colonisers. ${ }^{47}$

Second, Aboriginal perspectives, albeit mediated in large part by white scholars, were to be to the fore. This emphasis not only involved the kind of shift in moral

45 Barwick 1983; Beckett 1986: 81; Cowlishaw 1992: 23-25; Kijas 1992: 5-7; Kijas 1997: 52, 56.

46 'Aboriginal History aims to present articles and information in the field of Australian ethnohistory, particularly the post-contact history of the Aborigines and Torres Strait Islanders. Historical studies based on anthropological, archaeological, linguistic and sociological research, including comparative studies of other ethnic groups such as Pacific Islanders in Australia, will be welcomed. Future issues will include recorded oral traditions and biographies, vernacular narratives with translations, previous unpublished manuscript accounts, resumes of current events, archival and bibliographical articles, and book reviews' (The Journal of Aboriginal History: Scope and Management).

47 Barwick, Notes for Speech at the Launch of Vol. 1, 31 January 1978, Barwick Papers, Box 1, BARI02273; Barwick 1980: 7, her emphasis. 
viewpoint from the European to the indigenous that characterised recent work on colonialism. It also entailed a shift in the sense of one's standpoint so that one looked over the shoulders of the indigenous people or even through their eyes. Barwick stated emphatically in December 1976: 'Luise Hercus and I have been insisting that this [journal] must focus on Aboriginal history not white men's opinions'; and in May 1980 she asserted that white scholars 'must try to explain Aboriginal reaction in Aboriginal terms, or we are still telling the story from the white man's point of view'. This was one of the reasons why Barwick and Reece chose Stanner's article "“The History of Indifference Thus Begins"' to open the first volume of the journal. 'It is unique in emphasising the Aboriginal perception of historical events', Barwick told its author. 'This is precisely what we want for the journal[:] the perception that Australian historians have not - probably cannot - provide.' In Barwick's eyes, Stanner's was a 'great paper' because, apart from its focus on Aboriginal agency during the first sustained encounter between Aboriginal people and the British at Botany Bay and Port Jackson, it provided what she called 'an inversion of the white perceptions'. Here, too, at least in its stress on Aboriginal perspectives, Aboriginal history departed from the history of colonialism: whereas the latter tended to assume that colonialism had simply led to the destruction, degradation and decline of Aboriginal culture and sought to tell the story of this phenomenon, Aboriginal history assumed the survival of an autonomous indigenous world and tried to tell a story of its adaptation to the colonial presence and the ways in which this continued to shape Aboriginal people and their sense of themselves. ${ }^{48}$

Barwick as well as Gunson, Hercus and McBryde assumed that the work of Aboriginal History and Aboriginal history more generally should be interdisciplinary in nature or even that it had to be an inter-disciplinary enterprise in order to be able to focus on Aboriginal perspectives. In their opinion the discipline of history was not up to the task. This position had consequences for much of the editorial work that had to be undertaken in the first year or so of the journal's life. Some of these tasks were merely technical: a particular system of referencing was devised, which more or less amounted to an amalgam of the in-text (Harvard) style and the documentary-note (Oxford) style, in order to accommodate the range of disciplines that would be represented (as well as to make references accessible to general readers); and varitypists or typesetters were found in order to reproduce the particular type style or styles used in Aboriginal language texts. At the same time, agreement had to be reached in regard to the nature of authorship statements for material that was the product of collaboration between non-Aboriginal scholars and Aboriginal story-tellers, which had traditionally appeared under the name of the former only. There was more or less a consensus about such matters among the members of the editorial board. The same could not be said of a much larger issue, namely the very nature of the journal's enterprise. ${ }^{49}$

48 Barwick to WEH Stanner, 12 December 1976, her emphasis, Barwick Papers, Box 7, BARI02629; Barwick to Bruce Sommer, 20 February 1978, Barwick Papers, Box 1, BARI01545; Barwick 1980: 2, 13; McBryde 1996: 2-3, 10-12.

49 Barwick to Reece, 19 October 1977; Barwick to Bruce Shaw, 2 July 1978, Barwick Papers, Box 1, BARI02272; Urry, Circular letter, undated [c. mid 1978], Barwick Papers, Box 6, BARI02502; Barwick to Julie Rigg, 11 July 1978, Barwick Papers, Box 1, BARI02273; Shaw to Barwick, 13 
Barwick believed that the approach most historians adopted in the field of 'Aboriginal history' was deeply problematic. Indeed, in her eyes, their work merely amounted to studies of 'race relations'. By this, she meant that it was unduly preoccupied with the history of colonialism. To Barwick's way of thinking, Aboriginal history was the kind of work that Luise Hercus and Peter Sutton had recently produced: a volume of Aboriginal people's stories regarding the contact experience that were drawn from their oral traditions and told in their own languages (which Hercus and Sutton had persuaded their fellow linguists to make available even though few of them had much historical interest in those texts). ${ }^{50}$ Barwick made this opinion plain in much of her correspondence. In October 1978, in the course of urging the geographer Fay Gale to consider some of her students' theses for contributions to the journal, she emphasised: 'I'd like something from the Aborigines' point of view, not more race relations from documents, which is all the historians are doing'; and earlier that year, as she advised the anthropologist Bruce Shaw what he might submit, she complained: 'The historians have published innumerable studies from documents which gives only [the] white man's view'. In March 1979, in the course of encouraging the Aboriginal historian Bill Rosser to submit material to the journal, she clarified what she was after: 'I want Aboriginal History to emphasise Aborigines as actors in history; [and provide] the view from the other side'. Consequently, she called upon authors to produce accounts that focused on Aboriginal agency and Aboriginal perspectives. For instance, she asked Shaw to prepare an article that might be 'an Aboriginal version of employment on a particular cattle station, or a reminiscence of a massacre, or recollections of early contact or encounters with specific Europeans'. In adopting this approach, Barwick was very conscious that Aboriginal accounts could differ markedly from academic ones. As she later observed in her important essay 'Writing Aboriginal History', academic works, addressed to a white Australian audience, tended to focus on the oppression and hardship of Aboriginal people and sought to not only instruct but reproach their readers. By contrast, Aboriginal accounts, usually intended for both settler and Aboriginal audiences, revealed a greater range of experience and feeling and were less inclined to pass judgement on those who acted badly. Writing about one of these histories, Barwick pointed out: 'the funny bits are told with relish and explained in more detail than the poverty, prejudice and official decision which formed the inescapable framework of Aboriginal life' ${ }^{51}$

July 1978, Gunson Papers; Minutes of Aboriginal History Editorial Board Meeting, 14 July 1978, Barwick Papers, Box 2, BARI02410; Barwick to Sylvia Hallam, 1 September 1978, Barwick Papers, Box 3, BARI02436; Barwick, Abstract for Current Developments in Aboriginal History, Barwick Papers, Series 4007, Box 2, BARI01511; Barwick 1980: 13; Isabel McBryde, Proposal for a thematic issue of Aboriginal History devoted to interdisciplinary studies of Aboriginal Societies in South-Eastern Australia, 16 July 1982, Barwick Papers, Box 5, BARI02468; Diane Barwick, Aboriginal History: Editorial Responsibilities and Board Policy, 18 March 1983, Barwick Papers, Box 1, BARI00136; Gunson, Retiring Editor's Report, undated [c. 1987], Gunson Papers.

50 The volume appeared several years later: Hercus and Sutton 1986.

51 Barwick to Shaw, 20 February 1978, Barwick Papers, Box 1, BARI01545; Barwick to Donald McKaskill, 26 May 1978, Barwick Papers, Box 1, BARI02273; Barwick to Edgar Wells, 17 June 1978, Barwick Papers, Box 3, BARI02430; Barwick to Fay Gale, Barwick Papers, Box 3, BARI02432; Barwick to Bill Rosser, 14 March 1979, Barwick Papers, Box 3, BARI02431; Barwick 1980: 4; 
Barwick's position on Aboriginal history, as we have already noted, grew in large part out of her own research experience. She had become convinced that accounts of the past that relied upon documentary records provided at best a partial understanding, primarily because they contained very little of the worldview of Aboriginal people. She was particularly interested in revealing how history, both as a past and as accounts of that past, lived in the present. In order to provide Aboriginal perspectives, or what she often called the view from the other side', Barwick believed that oral history had to be conducted. 'Documents written and preserved by only half the participants in historical events are likely to tell only half the story', she wrote. 'Other records have been preserved in the oral history of Aboriginal communities.' At this time a small but growing number of historians in the west were beginning to realise the potential of oral sources to recover the lives of those said to have been 'hidden from history'. Most notably, the English historian Paul Thompson had published in 1978 his seminar text The Voice of the Past. But many historians in Australia, as elsewhere, remained wary of the method of oral history and drew attention to the vagaries of memory. In the early years of the journal Barwick saw to it that a good deal of material involving Aboriginal oral material was published in its pages. As she commented in a reader's report she wrote on Hercus' article 'Tales of Njadu-dagali (Rib-Bone Billy)', which was to appear in the first volume of the journal, 'I think the use of Aboriginal-language texts is very important for the proposed Journal of Aboriginal History'. In publishing what largely amounted to Aboriginal authored texts, Barwick urged the journal's board to adopt a policy that ensured they were given the same status as academic articles submitted by white scholars. Recommending the publication of Hercus' 'Tales', she pleaded: 'Can such MSS stand alone rather than being submerged in an "oral history department" as somehow separate (inferior?) to white-man-history?' In due course Barwick was very pleased that the journal had published Francesca Merlan's "'Making People Quiet" in the Pastoral North: Reminiscences of Elsey Station', Bruce Shaw's 'They Did it Themselves: Reminiscences of Seventy Years', and Peter Read's 'The Price of Tobacco: The Journey of the Warlmala to Wave Hill', in its first two volumes, in large part because she believed that they were instructive examples of the different ways 'oral history' could be deployed to good effect. ${ }^{52}$

Barwick championed the use of oral history for several reasons. She believed that it could not only provide Aboriginal perspectives but help make sense of documentary sources and so ensure a more accurate account of the past. As this might suggest, Barwick's approach to understanding the past was fundamentally empirical, as indeed was the approach of historians like Thompson. She tended

Barwick 1981: 75, 77, 79, 83; Barwick, Aboriginal History: Editorial Responsibilities and Board Policy, 18 March 1983, Barwick Papers, Box 1, BARI00136; Hercus and Sutton 1986: 1, 4; Urry to author, 7 February 2012.

52 Barwick, Report on Hercus, 'Tales of Nadu-Dagili', 24 March 1977, Barwick Papers, Box 7, BARI02629; Barwick to Shaw, 20 February 1978; Barwick to Francesca Merlan, 2 July 1978, Barwick Papers, Box 2, BARI02399; Barwick to Rosser, 14 March 1979; Barwick to Rosser, 9 April 1979, Barwick Papers, Box 3, BARI02431; Barwick, Mace and Stannage 1979: vii. 
to be very critical of any work that relied upon oral history alone. This led her to damn a book that was widely acclaimed on its publication in 1977: The Two Worlds of Jimmie Barker. Had its compiler, Janet Mathews, consulted the documentary record, Barwick insisted, she would have been sceptical of some of her informant's claims. After reading the manuscript of her fellow editor's review of this book for the first volume of the journal, which revealed that Reece had accepted the veracity of Barker's testimony, Barwick dashed off a letter chastising him: 'For a serious history journal of this kind I think the reviewer ought to regret that the author was not aware of written sources and did not question the old man about specific happenings' ${ }^{53}$ This, Barwick added, would have enabled 'the dual perceptions' (provided by the oral and the documentary sources) to be 'put side by side'; that is, they could be compared and consequently Mathews' text would have been corrected. ${ }^{54}$

Barwick was similarly emphatic that scholars working in the field of Aboriginal history needed to draw on the discipline of anthropology, or more especially the work of ethnography in order to understand the Aboriginal past. "Too few of the historians writing about contact really understand the culture of the Australian Aborigines', she was inclined to say. This was a further reason why Barwick and Reece selected Stanner's "“The History of Indifference"' as the lead article for the journal's opening volume. In that article Stanner largely sought to understand the Aboriginal response to contact by reading the journals, letters and despatches of the intruders in the light of his knowledge of Aboriginal customs and conventions. By doing this, he was able to draw into question long held Anglo-Celtic assumptions about the ways in which Aboriginal people had reacted to the British presence. One example must suffice. 'The records make much of the Aborigines' apparent hostility', Stanner noted. 'But the shaken spears did not necessarily indicate outright hostility', he argued. 'Universally, the Aborigines used such gestures at all meetings of great significance; there was always something of ritual in them; and curiosity must have been at least equal to fear or anger. ${ }^{55}$

By this time the historian Henry Reynolds had already begun to draw upon anthropological approaches in order to understand the Aboriginal response to their conquest and dispossession. ${ }^{56}$ Barwick, McBryde and Urry welcomed this work but they were nonetheless critical of it. They thought that Reynolds, in common with most historians, tended to make sweeping generalisations about Aboriginal culture and history rather than attending to its spatial and temporal variations. Here was another dimension of what the journal's editors had in mind for Aboriginal history, namely a focus on the Aboriginal in the sense of the local, as in the traditional use of the word 'aborigines' or ab origine: 'those

53 Reece revised his review of the book in the wake of Barwick's trenchant criticism (cf Reece, ms of his review, Barwick Papers, Box 2, BARI02403, and Reece 1979: especially 162).

54 Barwick to Reece, 7 November 1977, Barwick Papers, Box 2, BARI02403; Barwick to Shaw, February 1978; Barwick to Rosser, 9 April 1979; Thomson 2007: 52.

55 Stanner 1977: 5; Barwick 1980: 2.

56 See Reynolds 1976 and 1978a. 
believed to have been the inhabitants of a country [or place]'. In the light of this criticism, the journal's editorial board welcomed a short paper Reynolds submitted (after Barwick had asked him if he had anything sitting in a drawer that might be of interest). As McBryde observed, 'I was glad to see the paper confining its study to one region, which allows the comprehensive examination of all evidence and avoids the sweeping generalisation that must have regional exceptions. We need to base our knowledge of contact history more firmly in the detailed regional study before embarking on far reaching analysis'. In keeping with this emphasis, the journal's board developed a policy of encouraging its authors to refer to Aboriginal people by their 'clan/tribe/language or regional name'. ${ }^{57}$

This emphasis on the aboriginal further distinguished Aboriginal history from the historical work focusing on colonialism. This approach was articulated most clearly in an article Reece later wrote, 'Inventing Aborigines'. After noting that Aborigines were a by-product of the European colonisation of the country (in the sense that they had only come to have a common culture and a common consciousness as a consequence of that past), he asserted that historians were guilty of inventing a kind of national history for the Aboriginal people that distorted understanding of their past. 'Although doubt has been cast on the validity and usefulness of national historiography itself, there seems to be a naïve need to generalise about "the [Aboriginal] experience",', Reece argued. 'This does not mean', he hastened to add, 'that European Australians cannot or should not write Aboriginal history, but that they should be more cautious in writing about an entity which has been fictional until recent times'. Consequently, Reece suggested that Aboriginal history should largely comprise local histories. ${ }^{58}$

In fact the editors of Aboriginal History were critical of a good deal of the research that historians had done on the post-contact Aboriginal past. In particular they were troubled by the dominance of the concepts such 'the frontier' and 'resistance'. In their opinion, this was problematic for several reasons. First, the stress placed on conflict overshadowed the other ways Aboriginal people and settlers had related to one another. 'Many of us are outraged by the cruelty and dishonesty of settlers and governments', Barwick was to observe in 1980. 'But the contact process is a complex cultural pattern.' Second, Aboriginal people tended to be caricatured as the vanquished, which denied them any agency in the history of contact. 'Aborigines', Barwick insisted, 'were not passive objects of European attentions'. Third, so much attention was being paid to the violence committed by Europeans that the phenomenon of Aboriginal people killing one another,

57 Henry Reynolds to Barwick, 6 March [1978], Barwick Papers, Box 1, BARI02272; Barwick to Reynolds, 15 March 1978, Barwick Papers, Box 1, BARI02272; Referees' Reports on Reynolds, 'Before the Instant of Contact', 23 March 1978, 3 April 1978 and c. April 1978, Barwick Papers, Box 2, BARI02402; Barwick, Comments on ms of Andrew Markus, Review Article, 11 July 1977, Barwick Papers, Box 7, BARI02629; Urry 1978; Reynolds to Barwick, 29 May 1978, Barwick Papers, Box 1, BARI02272; Barwick, Aboriginal History: Editorial Responsibilities and Board Policy, 18 March 1983; Ramson 1988, entry for 'Aborigines', see <http://203.166.81.53/and/ index.php> accessed 14 February 2012.

58 Reece 1987: 14-15. 
and the fact that the frontier was not a common front on the Aboriginal side, had been overlooked. 'What impressed me most is the unabashed reminiscence about Aborigines killing each other', Barwick told Shaw after reading the manuscript of his book My Country of the Pelican Dreaming. Fourth, while the editors of the journal recognised that the new revisionist history of the Aboriginal-European encounter could have political consequences, ${ }^{59}$ they were critical of authors who seemed to be more interested in passing judgement on the past than in trying to understand it. Indeed, as we have already observed, they were committed to the pursuit of dispassionate, reasoned, scholarly inquiry. ${ }^{60}$

Most of the criticisms the journal's principal figures made of the work of historians were variations on a theme: it was too Eurocentric. But the editorial board's wish to focus on Aboriginal people, agency and perspectives meant that it was often reluctant to publish studies that might otherwise be regarded as research that advanced historical understanding of the post-contact history of Aboriginal people and which was accepted for publication by journals devoted to Australian history. Perhaps the best example of this was the editorial board's response to a paper the historian Alan Frost submitted in 1980, 'Of Distant Lands and their Peoples'. In it Frost sought to explain why the British had acted in the late eighteenth century as though the Australian continent had no Aboriginal owners and so had seen no need to negotiate for cession of land. Most of the journal's editorial board were critical of the fact that this paper did not shed any real light on Aboriginal people or culture ${ }^{61}$ As one referee observed, 'Frost has sufficient material to express the European attitude of applying terra nullius to the Australian situation, using his historical references to support his argument. With a little more research he could indicate what was the make-up of Aboriginal society at the time of European contact' ${ }^{62}$ The historian Peter Read, who joined the editorial board in 1981, was more or less expressing what had become the

59 Indeed, they sought to ensure that the journal would be a force for reform in scholarly practices. For example, they directed authors to pay attention to the nature of their language by avoiding terms such as 'half-caste' and 'full-blood' and to seek expert advice on matters that might offend Aboriginal conventions of propriety and privacy (Barwick, Memo for Editorial Board Meeting 8 September 1978 re the use of expletives and obscenities in quoted texts, and Minutes of Aboriginal History Editorial Board Meeting, 13 October 1978, Gunson Papers; Barwick to Richard Broome, 18 July 1980, Barwick Papers, Box 3, BARI02438; Barwick, Aboriginal History: Editorial Responsibilities and Board Policy, 18 March 1983).

60 Barwick to Sutton, 17 March 1978, Barwick Papers, Box 3, BARI02432; Referees' Reports on Reynolds, "'Before the Instant of Contact"', 3 April 1978 and c. April 1978; Barwick to Shaw, 20 October 1978, Barwick Papers, Box 1, BARI02272; Barwick 1980: 12-13; Urry to Sandy Yarwood, 15 October 1980, and Urry to John Stanton, 22 January 1981, Barwick Papers, Box 4, BARI02439; Hercus and Sutton 1986: 2-3; Reece 1987: 15-16; Hercus, interview with author, 18 January 2012; Urry to author, 7 February 2012.

61 Frost declined the Board's invitation to undertake major revision of his paper and offered it instead to the editor of Historical Studies (since retitled Australian Historical Studies), John Hirst, who promptly accepted it (Frost to Urry, 14 October 1980 and 14 January 1981, Barwick Papers, Box 4, BARI02439; Frost 1981).

62 This matter had contemporary legal and political implications, as one referee observed: '[Frost] would then be in a position to compare the two and, I suspect, the end result would be a rejection of the Europeans' concept of applying terra nullius to the Australian situation' (Referee's Report, 4 September 1980, Barwick Papers, Box 4, BARI02439). 
journal's policy when he commented, a year or so later: 'I think there should be a severe limitation on articles about whites in Aboriginal History, especially administrators, e.g. no more than one article per issue'. This was not merely a matter of policy but one of practice. The material that the journal published, at least in these early years, was distinctive. Much of it would not have been accepted by a more traditional kind of scholarly historical journal, which tended to place greater emphasis on causation, chronology and consequence. Indeed, it can be argued that only one or at most two of the articles published in each of the volumes printed in the journal's first ten years would have found a home in a conventional journal of historical studies (for example, those by John Ferry and WEH Stanner/Diane Barwick in vol 3, John and Leslie Haviland and Noel Loos in vol 4, and Gregory Lyons and Henry Reynolds in vol 7). ${ }^{63}$

In the light of what I have been arguing here it is probably not surprising that most of the scholarly articles published by the journal during Barwick's time in the editorial chair were authored by academics trained in the fields of anthropology, archaeology and linguistics rather than history. In each of the first three volumes only one in four of the scholarly articles published could be said to be the work of a historian. Furthermore, Barwick can only have regarded one of these as truly satisfactory, namely Lyndall Ryan's 'The Struggle for Recognition', which was an article in which its author had drawn on ethnohistorical, archaeological and historical sources to give an account of the emergence and development of distinctive 'part-Aboriginal' communities and life ways in Tasmania in the nineteenth century as they adapted the traditions of their Aboriginal and European forebears. ${ }^{64}$

In the early years of the journal Barwick expressed a wish 'to balance theoretical [and] descriptive articles', and in its first volume she and Reece published an article by Beckett that deployed the Marxist concept of internal colonialism in order to explain the modes of production at work in the Torres Strait pearling industry and the Island society's relationship with Australia. But Barwick had little interest in theory and preferred descriptive accounts, especially those that emphasised indigenous agency and perspectives. Most of all, she welcomed material that had a strong biographical focus. ${ }^{65}$ For instance, she was assiduous in encouraging Shaw and his students to produce Aboriginal life stories, and she warmly praised Beckett's account of George Dutton, which was published in the second volume, and Read's study of five Aboriginal men, which appeared in volume $4 .^{66}$

63 Ferry 1979; Stanner and Barwick 1979; Urry to Alan Frost, 16 September 1980 (and nine reader reports), Barwick Papers, Box 4, BARI02439; Haviland and Haviland 1980; Loos 1980; Gunson to Peter Read, 1 April 1981, Gunson Papers; Referee's Report on Bill Thorpe, 'The Protector as Hero', 19 October 1981, original emphases, Barwick Papers, Box 6, BARI02500; Lyons 1983; Reynolds 1983.

64 Barwick, List of letters to be sent to solicit contributions, undated [c. 1978], Barwick Papers, Box 2, BARI02425; Barwick to Stanner, 12 June 1980, Barwick Papers, Box 2, BARI02423.

65 For examples of Barwick's own biographical work, see Barwick 1985a and 1985b.

66 Barwick to Shaw, 20 February 1978; Barwick to Merlan, 2 July 1978; Barwick to Jeremy Beckett, 9 August 1978 and 6 September 1978, Barwick Papers, Box 2, BARI02442; Shaw to Barwick, 21 
Finally, in respect of Barwick's approach, she was eager to publish scholarly papers by Aboriginal authors in order to achieve what she called 'the double view of Aboriginal history'. Indeed, she worked hard to solicit contributions from the few Aboriginal people working in this way at the time. This was to no avail, though Barwick was able to publish some material that drew attention to the growing interest among Aboriginal people in the resources provided by the records and the remains of the past. For example, she commissioned a short article (by the anthropologist Athol Chase) describing a visit Aboriginal men from the Lockhart River in North Queensland had made to the National Museum of Victoria in Melbourne in order to see material the anthropologist Donald Thomson had collected in the 1920s and 1930s, and later the journal would publish pieces on black family history (by Niel Gunson) and Aboriginal community involvement in the founding of a university Aboriginal research centre (by Fay Gale). Furthermore, Barwick was assiduous in trying to recruit Aboriginal people for the journal's editorial board, though the terms of Marcia Langton, Gloria Brennan, John Newfong, and Les Malezer tended to be short as their services were in great demand by government or community bodies elsewhere in Australia. ${ }^{67}$

Given its path-breaking nature, it is not surprising that Aboriginal History experienced some moments of discord in its early years. In the course of 1977 serious conflict occurred, prompting what Barwick rightly called an 'editorial crisis'. This arose as a result of a clash over a book review Andrew Markus had asked a fellow historian Humphrey McQueen, one of Australia's most prolific reviewers, to write, ${ }^{68}$ but there can be no doubt that larger matters were at stake.

November 1978, Barwick Papers, Box 4, BARI02452; Barwick 1978: 13; Barwick to Lois Tilbrook, 22 January 1980, Barwick Papers, Box 2, BARI02319; Barwick to Read, 10 December 1980, Barwick Papers, Box 2, BARI02421; Hank Nelson to Urry, 26 June 1982, Barwick Papers, Box 5, BARI02483; Beckett to author, 8 February 2012.

67 Minutes of Aboriginal History Editorial Board Meeting, 10 March 1978, Gunson Papers; Barwick to Reece, 14 March 1978 and 21 April 1978, Barwick Papers, Box 1, BARI02274; Grimshaw to Gloria Brennan, 23 April 1979, Barwick Papers, Box 2, BARI02407; Barwick to Rosser, 14 March 1979; Barwick to Athol Chase, 23 March 1979, and Barwick to Markus, 23 March 1979, Barwick Papers, Box 3, BARI02429; Barwick to Susan Bulmer, 20 November 1979, Barwick Papers, Box 2, BARI02424; Chase 1979; Minutes of Aboriginal History Editorial Board Meeting, 18 January 1980, Barwick Papers, Box 2, BARI02423; Gunson to John Newfong, 18 February 1980, Gunson Papers; Aboriginal History Editors' Report 20 March 1980, Barwick Papers, Box 2, BARI02423; Barwick 1980: 5; Minutes of Aboriginal History Editorial Board Meeting, 29 May 1981, and Gunson to Les Malezer, 9 June 1981, Gunson Papers; Gunson 1981; Gale 1982; Minutes of Aboriginal History Editorial Board Meeting, 26 October 1984, Gunson Papers; McBryde, personal communication to author, 28 March 2012.

68 Two years earlier Gunson and Reece had invited McQueen, who had published a short book on Aborigines and racism in 1974, to serve on the journal's national committee, but he had declined on political grounds, telling them: 'I wish you well with your volume, will subscribe, and might even submit for publication. But because Marxism is such a frail blossom in Australia, I have drawn a line at being officially associated with other than Marxist publications - and even there I'm growing increasingly fastidious. In any case, my decision was confirmed by your intention to work through the [Australian Institute of Aboriginal Studies] which - irrespective of personnel - is a state apparatus' (Humphrey McQueen to Gunson and Reece, 18 October 1975, Gunson Papers). In the midst of the editorial crisis of late 1977, McQueen was to tell Barwick: 'In general, the whole business has merely confirmed my original decision not to be closely associated 
These concerned what the journal's editors should commission and/or accept for publication in terms of both articles and reviews, and who they should publish in disciplinary terms, which raised the question of which disciplinary practitioners should have the authority to decide these matters. These issues went to the heart of the question of what Aboriginal history should be as a historiographical project. At the same time there was a personal dimension to the conflict that occurred, and this should not be overlooked.

It is apparent that Barwick and Markus had radically different conceptions of the enterprise. Barwick had accepted an editorial role on the basis that the journal would place its emphasis upon Aboriginal people. By contrast, Markus' research, as well as the work he wanted to promote in the journal, focused for the most part on European racism and especially white Australian attitudes, ideas, laws, policies, practices and structures. ${ }^{69}$ This was evident in a review article he wrote for the first volume of the journal, 'Through a Glass Darkly', which was, appropriately, subtitled 'Aspects of Contact History' rather than 'Aspects of Aboriginal History'. It differed markedly from the articles in the same volume as well as a good part of a select bibliography whose preparation Barwick had overseen. Whereas their focus was upon Aboriginal people, his was not. ${ }^{70}$ As Barwick caustically but unfairly remarked in the course of making a series of highly critical page-by-page notes on a draft of Markus' review article: 'p. 9 "Lastly ... Aboriginal response" - this is typical of the extent of historical writing!' To make matters worse, Barwick believed that Markus wanted to turn the journal into a version of the journal Labour History, rather than promote Aboriginal history. (Markus had been the assistant editor of Labour History during 1976-77 and had remained a member of its editorial board after joining the board of Aboriginal History.) In keeping with these differences, Markus rejected Barwick's claim that Hercus' 'Tales of Nadu-Dagli (Rib-Bone Billy)' was ground breaking, and insisted that a paper by fellow historian Ann Curthoys (who had a similar historical approach to his) should have been included in the first volume rather than the one by Ryan which focused on Aboriginal people and perspectives. To make matters worse, Markus had a poor opinion of the outcomes of the research that had been conducted since the revival of interest among historians in the field. 'Considering the amount of energy expended in the last ten years', he had remarked, 'the quality of the yield has been disappointing'. Moreover, he

with the whole project of a journal. Only my friendship with Andrew [Markus] allowed me to weaken to the point of promising a review'. He added: 'Perhaps journals are to academia what barricades are to insurrections: militarily useless, but the best way to see who is on the other side' (McQueen to Barwick, 28 October 1977, Barwick Papers, Box 2, BARI02403). Not surprisingly perhaps, this remark infuriated Barwick (Barwick to Reece, 18 November 1977, Barwick Papers, Box 1, BARI02403).

69 For the nature of Markus' work, see Markus 1974, Markus and Curthoys 1978, especially his essay ‘Talka Longa Mouth: Aborigines and the Labour Movement 1890-1970', Markus 1979 and Markus 1990, but cf Markus 1986, Johnson and Markus 1987, and Attwood and Markus 1999.

70 That this was the opinion of those such as McBryde seems to be evidenced by a remark she made to Barwick a few years later: 'We have not had a survey article on Aboriginal History and we really should!' (McBryde to Barwick, undated note [c. May 1980], Barwick Papers, Series 4007, Box 2, BARI01511, her emphases). 
was critical of the pioneering study of Charles Rowley, for which Barwick had undertaken research and which had drawn on Barwick's own work, and this rankled with her. ${ }^{71}$

Generational differences played a role in this conflict, Barwick having been born a year before World War Two began, Markus three years after it ended. By the mid to late 1970s, Barwick had worked in the field for some time; Markus was holding his first academic position. In particular, Barwick regarded Markus as something of an upstart, one of a younger generation of historians whom she accused of having 'hopped on the bandwagon' since Rowley had published his trilogy. More to the point, she felt that he did not recognise, let alone acknowledge, her claim to have considerable expertise on the basis of having worked in the field for 15 years. She felt slighted by Markus' consideration in his review article of the work done in the field, and found it necessary to point out to him that she had at least 'produced a book' (i.e. a monograph), unlike a historian whose work Markus had discussed at some length (Reynolds), ${ }^{72}$ and that he had overlooked the historical work that she as well as other anthropologists had done. But it is clear that the disciplinary background of the two interlocutors was the most important factor in this conflict. Barwick believed that those in the disciplines of anthropology, linguistics and prehistory had the most to offer, largely because the fieldwork they conducted tended to bring them into close contact with Aboriginal people who were often absent or anonymous in the documentary record. She argued that Markus knew few of the scholars in those disciplines and that this meant that he lacked the knowledge to choose appropriate reviewers. Markus believed history should be the dominant discipline, thought that Barwick lacked knowledge of and contacts among historians in the country, and doubted her competence to select papers submitted by historians. He was of the opinion, too, that any history worth its salt should strive to reveal something about both the causes and consequences of the past, which required a greater emphasis on colonial forces than Aboriginal ones, and he thought that some of the papers that Barwick championed did not meet these criteria. ${ }^{73}$

71 Rowley 1970b; Barwick, Comments on Markus draft of 'Through a Glass Darkly', 11 July 1977, Barwick Papers, Box 7, BARI02629; Barwick, File Notes, 14 November 1977, Barwick Papers, Box 2, BARI02404; Barwick to Reece, 18 November 1977, her emphasis; Reece to Barwick, 21 November 1977, Barwick Papers, Box 1, BARI02403; Front Matter, Labour History 33, 1977: [i]; Markus 1977: 172; Reece to Barwick, 26 January 1978, Barwick Papers, Box 1, BARI02274; Markus 1977: 171-172; Aboriginal History, Chairman's Report 1977-78, undated [c. March 1978], Gunson Papers; 'Current Research', Aboriginal History 2, 1978: 185; Kijas 1993: 84; Markus to the author, 10 January 2012.

72 Barwick was referring here to the book on Coranderrk she had authored and which was due to be published by the ANU Press. She later decided to withdraw the manuscript as she felt it needed more work. It was published posthumously in 1998 (in a monograph series the journal had begun two years earlier).

73 Barwick, Comments on Markus draft, her emphasis; Barwick, File Notes, 10 and 11 November 1977, Barwick Papers, Box 2, BARI02404; Barwick to Reece, 19 October 1977, Barwick Papers, Box 1, BARI02403; Barwick to Reece, 18 November 1977; Barwick to Reece, 21 November 1977, Barwick Papers, Box 2, BARI02403; Stannage to author, 8 March 2012. 
In the end this conflict boiled down to a question of how much autonomy the journal's principal editor and its review editor should have in performing their roles and to whom they should be responsible. Both Barwick and Markus felt the other had too much influence over what the journal would publish. Eventually, Markus requested that the matter be placed on the agenda for one of the editorial board's monthly meetings, after Barwick and Reece had sought to override his authority in respect of McQueen's review. He presented two proposals: first, that the review editor be responsible to the editorial board, rather than to the editor(s), as Barwick and Reece had been insisting, and that the selection of reviewers and books for review as well as the decision to publish reviews be determined by the review editor alone; and, second, that the selection of articles be decided by the editors and four specially designated members of the Board whom he hoped would be historians, rather than by the editor(s) after consultation with all the Board members. $^{74}$

In effect, Markus' proposals, or at least the latter one, raised the very question of what kind of historiographical enterprise Aboriginal History would be. This was recognised by the journal's key players. Gunson told the board in his chairman's report: 'As with most big ventures there have been some teething problems and some real problems. It is partly to consider some of these that we are holding this meeting. The basic issues for our attention are the questions of editorial responsibility and the nature of Aboriginal history'. Barwick responded to Markus' proposals by spelling out her conception of the journal: 'I accepted coeditorship on the assumption that this new journal would emphasise Aboriginal history, drawing on the expertise of historians, anthropologists, archaeologists and linguists who have undertaken extensive research in this broad field and would aim at an audience including all these disciplines as well as interested laymen and students'. She had since become aware, she complained, that her colleagues thought it should 'primarily [be] a history journal, explicitly modelled on the specialist journals Pacific History and Labour History'. Such journals, she argued, were not an appropriate model for Aboriginal History given its subject matter and the audience it was seeking to reach. 'This broad field', she insisted, 'is not the preserve of and cannot be mastered by members of any one discipline'. This consideration, Barwick argued, should determine the journal's editorial policies. In other words, in selecting scholarly articles and referees and in choosing books and book reviewers, the periodical had to be guided by the broad range of specialist knowledge held by members of the Board. Only this could ensure 'coverage of the field of Aboriginal history' ${ }^{75}$

74 Markus to Gunson, 15 August 1977, Reece to Barwick, 29 August 1977, and Reece to Markus, 29 August 1977, Gunson Papers; Markus to Barwick, 8 November 1977, Barwick Papers, Box 1, BARI02403; Barwick, File Notes, 11 November 1977; Agenda for Meeting of Aboriginal History Editorial Board Meeting 25 November 1977, 17 November 1977; Barwick to Reece, 21 November 1977, Barwick Papers, Box 1, BARI02403.

75 Aboriginal History: Chairman's Report for 1977, 24 November 1977, Barwick Papers, Box 1, BARI02403; Barwick, Amendment of Proposals 3 and 5: Editorial Responsibility and the Nature of Aboriginal History, [24 November 1977], her emphases, and Minutes of Aboriginal History Editorial Board Meeting, 25 November 1977, Barwick Papers, Box 2, BARI02403, her emphases, Barwick Papers, Box 2, BARI02403. 
In an unusually long meeting - nearly three hours - these matters were thrashed out. Markus won support for his proposal regarding the roles and responsibility of the review editor, though it was agreed that he should be guided by the knowledge of the Board's members in selecting books and choosing reviewers. But, more importantly, his proposal to circumscribe the authority Barwick had been exercising as the journal's editor was defeated. In fact, only one Board member, Curthoys, backed his motion along these lines. Gunson's support for Barwick's position might have played a crucial role here, though in the paper he had prepared for the meeting he had tried to caution both the warring parties: 'As to the nature of Aboriginal history, I hope it remains as wide a concept as possible[,] allowing both the closely documented research articles and the more imaginative and speculative reinterpretations. History is about evidence of man's activities but it is also about ideas, so we must be careful not to become too exclusive'. This said, nearly all of the board's members seem to have been predisposed towards a venture that focused on Aboriginal people, actors and points of view. At the meeting's close, Gunson wisely sought to reconcile the opposing parties by suggesting that the editorial arrangements for the next year remain more or less the same (though Reece would now become a 'corresponding editor' in the light of his appointment to a position at Murdoch University in Western Australia). Not for nothing did Barwick once describe Gunson as 'an experienced peace chief from Pacific History'. In the course of the following year, Markus would press for more representation for historians on the journal's board but to no effect. Barwick was increasingly able to impress her conception of Aboriginal history on the journal. ${ }^{76}$

The editorial board's commitment to developing the field of Aboriginal history determined a good deal of the journal's content in its early years, at least in what was called Part 2 of each number. ${ }^{77}$ Gunson in particular was determined to ensure that the emerging sub-discipline had solid foundations, which is why he took responsibility for the documents section. The journal's editors both commissioned and prepared material that was designed to draw attention to the available resources. An extensive bibliography of published and unpublished research on 'Aboriginal History and Social Change' was prepared (by Barwick, Urry and David Bennett) for the first volume; a series of pieces describing major archival and manuscript collections appeared in the subsequent five volumes; and the book reviews were regarded as a means of alerting readers and researchers to newly published books in the field. But the journal's editorial board also welcomed papers that revealed the enormous variety of source material that could be used in researching Aboriginal history, especially those in which Aboriginal people were prominent, hence the publication of articles on ethnographic film (Ian Dunlop), painting and drawing (George Chaloupka and

76 Aboriginal History: Chairman's Report for 1977; Minutes of Aboriginal History Editorial Board Meeting, 25 November 1977; Markus to Gunson, 28 April 1878, Gunson Papers; Minutes of Aboriginal History Editorial Board Meeting, 5 May 1978; Barwick 1980: 5.

77 The division of each volume of the journal into two parts was dictated by the conditions of the federal government's book bounty, which helped to offset the journal's costs. 
Carol Cooper), song (Tamsin Donaldson), ceremony (Luise Hercus and Isobel White), creative writing (Adam Shoemaker), language (Tom Dutton et al), music (Paul Black and Grace Koch), and myth (Peter Austin and Norman Tindale). ${ }^{78}$

During the early years of the journal Barwick became interested in publishing material that considered not only Aboriginal perceptions and perspectives on the past but also what might be called Aboriginal conceptions of history. In March 1978 the linguist Peter Sutton had made a series of observations about 'Aboriginal views of history' in a letter to Barwick and told her he would 'like to see some papers devoted to the investigation of Aboriginal historiography'. In response she encouraged him to write about 'Aboriginal notions of history' ${ }^{79}$ More particularly, she noted that the Belgian scholar Jan Vansina had studied African peoples' uses of myth as charter, and suggested it was time that the same was done in regard to Aboriginal people. ${ }^{80}$ In due course Barwick's interest in how Aboriginal and European approaches to representing the past differed from one another seems to have been sharpened by a statement a Working Party of Aboriginal Historians for the Bicentennial History made in 1981. In this declaration, she noted, they challenged 'the premise that Aboriginal history must satisfy historians' criteria of causation, chronology and writing style'. Yet it would seem that neither Barwick nor any of the members of the journal's editorial board were willing to embrace the kind of consideration that the exponents of cultural studies were beginning to devote to this matter. The journal rejected a paper submitted by Stephen Muecke entitled 'Discourse, History, Fiction: Language and Aboriginal History' that took the Working Party of Aboriginal Historians' statement as its point of departure and focused on an official account, an Aboriginal oral narrative and a novel regarding the Aboriginal figure Pigeon (or Jandamarra), largely because it failed to exhaust the various ways in which Pigeon's life story could be told, which included the kind of account an academic historian would provide. ${ }^{81}$

78 Document, undated [c. October 1975]; Barwick to Humphrey McQueen, 19 October 1977, Barwick Papers, Box 2, BARI02403; Archives and Publications, undated memo [c. 1977], Gunson Papers; Barwick to Bulmer, 30 November 1979; Barwick to Tilbrook, 22 January 1980.

79 Sutton eventually did so in an important essay. See Sutton 1988.

80 This said, the journal's editorial board was to reject a paper the anthropologist Erich Kolig submitted regarding the transition from mythical to historical thought among Aboriginal people on the grounds that it did not fit with the kind of work it was publishing (Erich Kolig to Barwick, 4 June 1980, Barwick Papers, Box 2, BARI02423; Editorial Board Decisions Required, 19 November 1980, Barwick Papers, Box 2, BARI02421; Urry to Erich Kolig, 25 November 1980, Barwick Papers, Box 4, BARI02441). An essay Kolig had published the previous year on Aboriginal Captain Cook stories (1979), which was more ethnographic in nature, would have been more to the journal's liking.

81 Referee's Report on Hercus, Tales of Nadu-Dagili; Peter Sutton to Barwick, 8 March 1978, and Barwick to Sutton, 17 March 1978, Barwick Papers, Box 3, BARI02432; Barwick to Sutton, 5 April 1979, Barwick Papers, Box 3, BARI02429; Working Party 1981; Barwick 1981: 80-81; Urry to Stephen Muecke, 18 January 1982, and Readers' Reports on his paper, Barwick Papers, Box 7, BARI02522. Muecke's paper found a home in the opening number of The Australian Journal of Cultural Studies. Later, Muecke co-authored a paper that was more along the lines the journal favoured, and this was accepted (Muecke, Rumsey and Wirrunwarra 1985). 
Barwick's commitment to promoting historical research by Aboriginal people led her to initiate one of the journal's most important ventures, the production of a guide to researching Aboriginal and Torres Strait Islander History, in order to cater for the growing number of Aboriginal people interested in telling their own people's history. She proposed this publication after persuading the Australian Institute of Aboriginal Studies to sponsor a workshop on oral history for Aboriginal people in June 1979. ${ }^{82}$ Her objects were as much political as they were pedagogical. As she advised the editorial board of Aboriginal History in March that year: 'I have stressed [to the Institute] that mere talk sessions and even tuition in oral history interviewing will not satisfy the needs of the practitioners and will provide little feed-back to their communities unless guidesheets are prepared covering the various topics in collecting historical material and the writing of history ... [And] until Aboriginal researchers have access to this kind of information they will not have real equality'. Barwick's co-editor, Tom Stannage, warmly embraced her plan. He had prepared a handbook on local history in Western Australia several years earlier. It would provide one model for the guide, a handbook for indigenous historians produced by the University of Papua New Guinea's journal Oral History another. Stannage believed that there would be great demand among university teachers for such a handbook. Together, he and Barwick persuaded the Board that most of the work could be done by its members and that it should be published by the journal as a supplement. They offered to serve as editors, and Michael Mace, the chairman of the Institute's Aboriginal and Torres Strait Islander Advisory Committee, lent support. Time was of the essence since Barwick wanted the handbook to be available at the workshop. In early April they asked a long list of contributors, most of whom were either members of the Board or on staff at the Australian Institute of Aboriginal Studies and ANU, to write short, informative essays and submit them by the end of the month. Most obliged, and after considerable editorial work in the course of the next month or so as well as an all-night stint by the printers, copies of the guide appeared at noon on the first day of the workshop. The handbook was remarkably comprehensive. The anthropologist Howard Morphy pointed out at the time that there were no essays on the visual arts, dance, oral literature (in the form of myth, poetry and song texts) and anthropological writings, but it nonetheless covered a large array of sources and crossed over many disciplines. Most importantly, it met a need. Before a year had passed, the first printing of some 1000 copies had been exhausted, and a second one was ordered, and by the autumn of 1984 a third print run was required. (By 1990, the handbook was in its fourth printing. $)^{83}$

82 For a report of this conference, see Anon 1979.

83 Barwick to Stannage, 16 February 1979, Barwick Papers, Box 2, BARI02407; Minutes of Aboriginal History Editorial Board Meeting, 16 March 1979, and Barwick, Confidential Memo: Project: Publication of a Supplement to Aboriginal History, 15 March 1979, Barwick Papers, Box 2, BARI02407; Stannage, Barwick and Michael Mace, Circular Letter, 4 April 1979, Stannage to Markus, 5 April 1979, and Instructions for Authors, undated [April 1979], Barwick Papers, Box 3, BARI02427; Barwick to Ted Thomas, 20 May 1979, and Barwick to Catherine Burke, 21 June 1979, Barwick Papers, Box 3, BARI02427; Barwick to Reece, 24 June 1979, Barwick Papers, Box 2, BARI02406; Howard Morphy to Barwick, Stannage and Mace, 26 June 1979, and Barwick to Burke, 31 July 1979, Barwick Papers, Box 3, BARI02427; Barwick, Mace and Stannage 1979: [vii], 
Apart from the emphasis the journal's editorial board placed on Aboriginal history in the various senses of that term, it is apparent that its key figures wanted to nurture research on particular aspects of the encounter between Aborigines and Europeans (and it might be noted that these were its preferred terms, rather than 'black' and 'white', because the latter pair was perceived to smack of a particular way of conceptualising cultural difference that the members of the editorial board abhorred). The second volume of the journal was headed 'The Impact of the Pastoral Industry' and it contained three scholarly articles (Jeremy Beckett's 'George Dutton's Country: Portrait of an Aboriginal Drover', Diane Bell's 'For our Families: The Kurundi Walk-Off and the Ngurrantiji Venture' and Francesca Merlan's "'Making People Quiet" in the Pastoral North') and two contributions in the 'Sources for Aboriginal History' (Bruce Shaw and Sandy McDonald's 'They Did it Themselves' and Peter Read and Engineer Jack Japaljarri's 'The Price of Tobacco'). Yet, as Barwick admitted, the choice of this theme had happened by chance. She would have preferred to devote a volume largely to the impact of the missions, especially if there could be material that told the story from both sides. Barwick was of the opinion that missions were, as she put it to one of her correspondents, 'the most important social change endeavour in Australia for the last century and more'. In fact she was dismayed by the tendency among her contemporaries to cast the missions as the destroyers of Aboriginal culture and she wanted to encourage work that captured the complexity of the encounter between missionary figures and Aboriginal people. Barwick set about trying to solicit material for a volume of the journal that would largely focus on missions, but insufficient material was submitted..$^{84}$

In late 1978 McBryde suggested the journal consider doing volumes along thematic or regional lines and commissioning members of the editorial board to take responsibility for these. Some Board members doubted that thematic issues would meet the journal's remit of being inter-disciplinary but the proposal was accepted nonetheless. Shortly after, Urry put forward a proposal for a special issue devoted to Aboriginal-Asian contact, which would pay special attention to relations between Aboriginal people and Chinese, Malays and Afghans, and this volume was scheduled for volume 4 and eventually made up volume 5 of the journal. A few years later McBryde (who had become the journal's review editor in mid 1979) proposed a special issue devoted to an inter-disciplinary consideration of questions of group identity, territories and group interaction among Aboriginal societies in southeastern Australia, which grew out of a series

[ix]; Minutes of Aboriginal History Editorial Board Meeting, 18 January 1980, and Barwick to Tom and Maria Stannage, 7 April 1980, Barwick Papers, Box 2, BARI02423; Aboriginal History Reports for 1980-81 and 1983-84, Barwick Papers, Box 1, BARI00136; Aboriginal History Report for 1989-90, 30 March 1990, Gunson Papers; Stannage to author, 8 March 2002.

84 Barwick to TGH Strehlow, 1 February 1978, Barwick Papers, Box 1, BARI02273; Barwick to Kay Saunders, 21 April 1978, Barwick Papers, Box 3, BARI02432; Barwick to Reece, 21 April 1978; Barwick to Edgar Wells, 17 June 1978, Barwick Papers, Box 3, BARI02430; Barwick to Reece, 21 November 1978, Barwick Papers, Box 1, BARI02274; Barwick to Saunders, 23 March 1979, Barwick Papers, Box 3, BARI02429; Minutes of Aboriginal History Editorial Board Meeting, 25 May 1979, Barwick Papers, Box 2, BARI02407; Barwick, Aboriginal History: Editorial Responsibilities and Board Policy, 18 March 1983; Isabel McBryde, personal communication to the author, 28 March 2012. 
of meetings of scholars working in this part of Australia that she convened, which appeared as volume 8. The journal's next volume was devoted to Aboriginal languages, and was overseen by Luise Hercus and Tom Dutton. ${ }^{85}$

At the outset, the journal's editors made clear their wish to nurture historical research that was not only inter-disciplinary in nature but comparative as well. The description of the work they were interested in publishing made reference to studies that compared the experience of Aboriginal people with that of other groups such as Pacific Islanders in Australia. Barwick was especially keen to publish studies that drew on the insights to be gained from comparative history. She believed that North America was a more useful comparator for Australia than South Africa or South America, the latter of which had been used by more than one author submitting work to the journal, simply because their post-contact pasts had greater similarities, but at this time Barwick was more or less alone in doing such work. ${ }^{86}$ In its second volume, the journal published a review article focusing on a recently published survey of the history of race relations in Australia and New Zealand, but Barwick was dismayed by what she saw as its author's simplistic discussion, and the journal published hardly any comparative studies, as historians increasingly abandoned such studies as they sought to focus on indigenous perspectives. ${ }^{87}$

So much for the directions in which the journal's key figures sought to take the field of Aboriginal history. What of its impact? The planners of Aboriginal History were by no means certain it would succeed, and the first number had already gone to press before the editorial board decided it would press ahead with the next one. Nonetheless, they were bold enough to order 1500 copies of the first volume. ${ }^{88}$ It soon became apparent that there was considerable interest in the journal. There was a pleasingly large number of subscriptions and sales for the first volume even before the board sought to advertise the journal, though it thought that history was less well represented among its subscribers than the

85 Minutes of Aboriginal History Editorial Board Meeting, 13 October 1978, Barwick Papers, Box 2, BARI02408; Urry, Proposal for a special issue of Aboriginal History devoted to the theme 'Aborigines and Asians', 9 November 1978, Barwick Papers, Box 7, BARI02523; Minutes of Aboriginal History Editorial Board Meeting, 17 November 1978, Barwick Papers, Box 2, BARI02408; Minutes of Aboriginal History Editorial Board Meeting, 20 April 1979, Barwick Papers, Box 2, BARI02407; Minutes of Aboriginal History Editorial Board Meeting, 25 May 1979; Grimshaw to Markus, 5 June 1979, Barwick Papers, Box 1, BARI02274; Minutes of Aboriginal History Editorial Board Meeting, 20 July 1979; Isabel McBryde, Proposal for a thematic issue of Aboriginal History devoted to interdisciplinary studies of Aboriginal Societies in South-Eastern Australia, 16 July 1982, Barwick Papers, Box 5, BARI02468.

86 In 1980 Barwick presented a paper at ANZAAS, 'Making a Treaty: The North American Experience' (copy held Barwick Papers, Series 4007, Box 2, BARI01522). This was published in the journal after her death: Barwick 1988.

87 The journal's aims, Aboriginal History 1, 1977, inside back cover; Barwick to Reece, 29 September 1978, Barwick Papers, Box 1, BARI02274; Hartwig 1978; Constitution of Aboriginal History, Barwick Papers, Box 1, BARI02274; Barwick to Heather Goodall, 4 February 1980, Barwick Papers, Box 4, BARI02446; Barwick 1980: 9; Montgomerie 1997: 155.

88 The same number of the next three volumes were printed, but it was agreed in 1981 that this number was excessive and that 1000 copies was a more sensible print run (Minutes of Aboriginal History Editorial Board Meeting, 21 August 1981, Barwick Papers, Box 6, BARI02497). Yet by 1988 vol 1 had sold out and a second printing had to be done (reprint of vol 1, inside front cover). 
disciplines of anthropology and archaeology. By the time the second volume had been published, sales and subscriptions had reached 800, enabling the journal to become self-supporting. The first two volumes sported an attractive cover based on figures discovered in an Aboriginal rock shelter in Cape York and designed by Barwick's husband Dick, a zoologist at ANU, and this might have helped sales in bookshops. ${ }^{89}$ Most importantly, the journal soon attracted a healthy number of submissions, nearly 30 in the case of the second volume, some of which seem to have been lying in drawers for want of a suitable forum for publication..$^{90}$ This interest made it easier for the journal's board to reject material it regarded as unsuitable for publication, which it often did in no uncertain terms. ${ }^{91}$

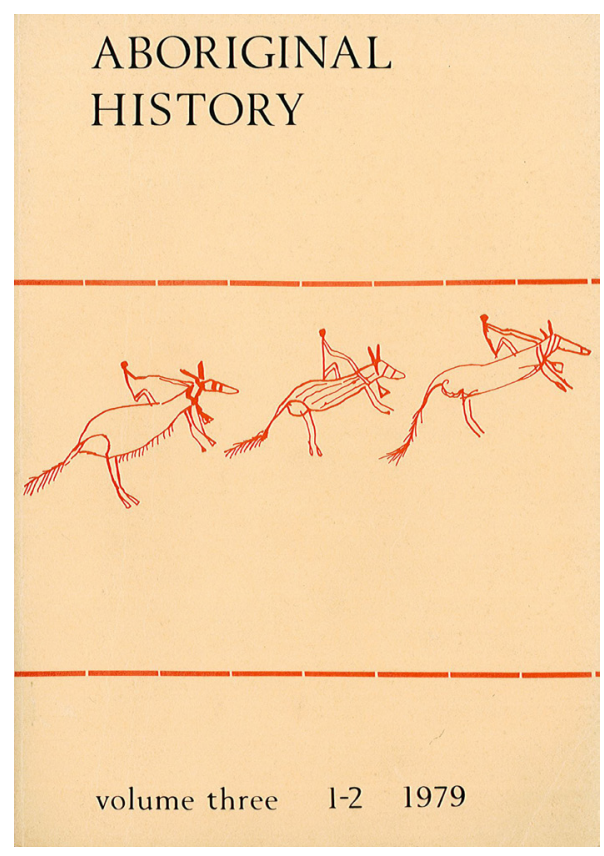

Illustration 3: Dick Barwick designed the covers for the journal for many years. This one, for vol 3, comprised the detail of an example of rock art in Magela Creek Catchment, Western Arnhem Land, known as the 'Pack Horse Scene'.

89 The image used for the cover of volumes 1 and 2 can be seen in Illustration 1 . Thereafter, nearly every volume, at Urry's suggestion it seems, had its own particular design, devised by Dick Barwick but based on an Aboriginal drawing, engraving or painting (Urry to author, 7 February 2012).

90 This included a paper by Stanner on 'Aboriginal Humour', which had been written in 1956. Barwick encouraged him to offer this to the journal in 1980 (Barwick to Stanner, 12 June 1980, Barwick Papers, Box 2, BARI02423), and it was published in vol 6.

91 Minutes of Aboriginal History Editorial Board Meeting, 25 November 1977; Minutes of Aboriginal History Editorial Board Meeting, 10 February 1978; Barwick to Strehlow, 9 March 1978, Barwick to Reynolds, 15 March 1978; Barwick to Peterson, 18 May 1978, Barwick to Julie Rigg, 11 July 1978, Barwick Papers, Box 1, BARI02273; Aboriginal History Publicity Committee, Informal Notes, presented to meeting 8 September 1978, and List of the purchasers of vols 1-3, undated, Barwick Papers, Box 2, BARI02408; Memo, 24 September 1979, Barwick Papers, Box 2, BARI02406. Barwick 1980: 6; Aboriginal History, Report for 1980-81, March 1982, Barwick Papers, Box 1, BARI00136; Yarwood to Barwick, 23 October 1980, Barwick Papers, Box 3, BARI02433; Kenneth Liberman to Barwick, 6 February 1981, Gunson Papers; Minutes of Aboriginal History Editorial Board Meeting, 20 February 1981, Barwick Papers, Box 6, BARI02498. 
Tracing the influence of a book or a journal upon an area of scholarship is never easy. It might be argued that the journal's conception of Aboriginal history influenced the direction that historical scholarship took in the field in the 1980s. Yet what might be described as an Aboriginal turn in historical work has more often than not been attributed to Henry Reynolds' 1981 book The Other Side of the Frontier rather than to the journal. ${ }^{92}$ Reynolds' approach was in keeping with one championed by the journal's editors, and a good deal of what he considered in his monograph as well as the papers he wrote earlier was anticipated by research undertaken or overseen by McBryde. Nevertheless, his work undoubtedly had more impact on historians than the material published by the journal. There are several reasons for this but one of these is especially worthy of our attention here. Reynolds' purpose in The Other Side of the Frontier was rather different to that of the journal. He cast the history of Australia from an Aboriginal perspective not so much because he wanted to grapple with the nature of Aboriginal people's experience but because he wanted settler Australians to empathise with the Aborigines' dark past and thereby become supporters of a political struggle seeking to ensure that Aboriginal people would become citizens of the Australian nation state. In other words, there is a sense in which his approach, unlike the journal's, remained a Eurocentric one, and thus one that could be more readily put to use in the principal Australian public domains. Arguably, there was a tension from the beginning in the field of 'Aboriginal history' between those who wanted to use accounts of the Aboriginal past in this realm to serve what they saw as the needs of both Aboriginal people and the Australian nation, and those who were more concerned to serve what they saw as the needs of Aboriginal people in domains that were more of their own making. ${ }^{93}$

It might be argued, furthermore, that the journal's particular conception of Aboriginal history, and its stress on the inter-disciplinary work it believed was required to fulfil this project, deterred many historians from submitting work and so diminished the amount of influence it might have had. The editorial board's commitment to its particular definition of Aboriginal history was questioned at the outset of the journal's life. The historian Jo Woolmington welcomed its emphasis on Aboriginal people but queried whether there would be any place for research of the kind she was conducting at the time, namely a study of the English humanitarians of the 1830s and 1840s. This, it might be argued, lay at the heart of the concerns Markus had expressed during the journal's early editorial crisis. A decade later, Gunson would observe that 'good articles on Aboriginal History were being published in other historical journals' and express concern that the journal was 'in danger of being regarded as too esoteric'. I will return to this matter at the end of this article. In the meantime I wish to consider the way in which Barwick went about performing the role of the journal's editor and the impact this had upon her. ${ }^{94}$

92 For a discussion of The Other Side of the Frontier and its publication, see Attwood and Griffiths 2009: 11-19.

93 McBryde, Report on Reynolds, 'Before the Instant of Contact', 23 March 1978; Urry, Report on Reynolds, 'Before the Instant of Contact', 3 April 1978; Attwood 2011: 176.

94 Jo Woolmington to Gunson and Reece, 27 October 1975, Gunson Papers; Gunson, Retiring Editor's Report. 


\section{The burden of the editor}

Whatever influence the journal might have had, the production of it during its early years undoubtedly took a toll on its principal editor, Diane Barwick. Although the support provided by the Research Schools of Pacific Studies and Social Sciences had enabled the venture to begin, it never secured the kind of university sponsorship enjoyed by the most prestigious historical journals in Australia such as Historical Studies. This meant it was never able to engage a full- or even a part-time officer to undertake the numerous mundane tasks involved in the publication of a periodical (though the board enjoyed wonderful secretarial assistance, provided by May Mackenzie and paid for by the Research Schools of Pacific Studies and Social Sciences). Most of this time-consuming work, which was made worse by the numerous failings of the journal's printer, was undertaken by Barwick. (All of the volumes produced during her editorship were plagued by printing problems and only appeared in the year following their publication date. $)^{95}$

The burden was all the greater because of the manner in which Barwick tackled the task of editor. The journal became a labour of love for her, and her commitment to it was out of the ordinary. There are probably several reasons for this apart from the intellectual and political ones canvassed previously. Barwick's position in the academy, as we observed earlier, was a tenuous one. While her research was greatly admired by the likes of John Mulvaney and Charles Rowley, it was held by many to fall between the fields of anthropology and history and thus met the requirements of neither discipline. Barwick, partly as a consequence of this perception, only held two one-year full-time academic positions during the period under consideration here, and neither of these proved very satisfactory. ${ }^{96}$ The marginal position Barwick felt she occupied increasingly rankled with her, and perhaps all the more so as the impact of second-wave feminism on Australian universities deepened. At various times she described herself as 'unemployed' and 'an unfunded housewife scholar', and in her author notes for publications

95 Gunson, Proposal for University Sponsorship of Aboriginal History, for Discussion at Editorial Board Meeting of 20 February 1981, 26 January 1981, Barwick Papers, Box 5, BARI02469; Minutes of Aboriginal History Editorial Board Meeting, 1 August 1984, Gunson Papers; Gunson, interview with author, 18 January 2012.

96 In the case of the first, a one-year lectureship in 1978 in the Department of Prehistory and Anthropology in the School of General Studies, Barwick felt unappreciated more or less from the outset, and even complained that she felt like 'a pariah' among the anthropologists there. In the case of the second, a one-year research fellowship in 1979-80 in Inglis' Department of History in the Research School of Social Sciences, Barwick enjoyed the company there but confessed to feeling like 'a cuckoo in the historians' nest' as she was convinced that her appointment struck her colleagues as 'very strange' (Barwick to Reece, 5 January 1978, Barwick Papers, Series 17, Box 1, BARI02274; Barwick to Lyndall Ryan, 6 April 1978, Barwick Papers, Box 1, BARI02273; Barwick to Francesca Merlan, 2 July 1978, Barwick Papers, Box 2, BARI02399; Barwick to Reece, 24 June 1979). According to Peter Read, historians in the Department of History were baffled by the seminar presentation Barwick gave during her fellowship which featured a detailed account of genealogical connections between Aboriginal people that were central to her treatment of the history of Coranderrk (Kijas 1993: 80-81; Peter Read, personal communication, 19 January 2012). 
she provided her residential address instead of an institutional affiliation. The worse Barwick's position became in the academy, the more she threw herself into her role as editor of Aboriginal History. ${ }^{97}$

There seems to be further reasons why the journal's editorship became so important to Barwick. Although she gave the impression of being very sure in her opinions and could be very forthright in expressing these, she lacked confidence in her own research. In this context the role of critic must have become an increasingly attractive one. Barwick once quipped to Lyndall Ryan: 'of course it is much easier to criticise than to write!' By immersing herself in the work of the journal she might even have been trying to escape from her own writing tasks. While she had authored several essays and a book manuscript between the early 1960s and early 1970s, Barwick found it increasingly difficult to complete substantive pieces of research. ${ }^{98}$ Consequently she seems to have not only adopted the role of a midwife but assumed the part of a ventriloquist, rewriting or perhaps even writing parts of the articles on which she worked. In many cases her editorial interventions enhanced an author's treatment of a subject, and in others it ensured that research was published that would have otherwise remained buried in a drawer. ${ }^{99}$ This work brought Barwick recognition

97 Barwick to Reece, 7 January 1979, Barwick Papers, Box 1, BARI02274; Barwick, 'Editors' Report, 17 November 1978, Barwick Papers, Box 2, BARI02408; Barwick, Memo, 15 March 1979; Draft of List of Contributors for Handbook for Aboriginal and Islander History, undated [c. May 1980], Barwick Papers, Box 3, BARI02428; Barwick, Mace and Stannage 1979: [ix]; Barwick to Grant McCall, 22 July 1982, Barwick Papers, Box 5, BARI02468; Barwick to Marie Fels, undated [c. 1984], Barwick Papers, Box 1, BARI01545; Reece 1986b: 71, my emphasis; Stannage to author, 8 March 2012.

98 This pattern of publication can be traced in Barwick 1988: 2-4.

99 This was the case with Stanner's famous 'The History of Indifference Thus Begins', which had begun its life in 1964 as a chapter for a projected book on Australian Aborigines that Stanner had been contracted to write by an American publisher but which he had abandoned (Len Bloom to Stanner, 14 June 1960, Contract between Chandler Publishing Company, San Francisco and Stanner, November 1960, Bloom to Stanner, 28 September 1964, Stanner Papers, Item 224(a); Stanner 1977: 3). After reading Stanner's first draft of this chapter Barwick suggested a number of changes, which included shifting some discussion from the footnotes into the text, explaining some anthropological matters in order to ensure that readers were able to grasp his account of Aboriginal perceptions of Europeans, and adding a new title - Stanner's chapter had been called both 'Foundation and Pattern' and 'Foundations' (Barwick to Stanner, 12 December 1976; Barwick to Stanner, 11 June 1977, and Stanner to Barwick, undated [c. June 1977], Barwick Papers, Box 7 , BARI02629; Barwick, undated note on a copy of 'Foundation and Pattern', Stanner Papers, File 225(a)). In case my account here as well as one by Ann Curthoys (2008: 240) might lead readers to conclude that Barwick's contribution to Stanner's article was more important than it actually was, I will make a couple of points. First, the anthropologist Len Bloom (who had commissioned Stanner to write the book for a series for which he was the editor) had previously suggested to Stanner that he move discursive material in his footnotes into the text (Bloom to Stanner, 28 September 1964), and Stanner had done this in the course of revising the chapter for his book (copy of 'Foundations', held Stanner Papers, Series 1, Item 225[a]). (Barwick had read an earlier version of the essay and so was unaware Stanner had made this change [Stanner, 'Foundation and Pattern', ms with Barwick's annotations, Stanner Papers, Series 1, Item 225(c)].) Second, and more importantly, Stanner had in any case placed considerable emphasis in his original chapter on the ways in which Aboriginal people might have understood their early encounter with Europeans, and while he happily acted upon a series of editorial suggestions Barwick made (see Stanner annotations on a copy of Barwick to Stanner, 12 December 1976, Barwick Papers, Box 7, BARI02629), these did not change the article in any substantial sense (cf 'Foundation and 
but it was for her as an editor rather than an author. In all this, it might be argued, Barwick was typical of many academic women of her generation, who had been taught to regard themselves as helpmeets to senior male colleagues. ${ }^{100}$

Barwick has rightfully been remembered as a dedicated and a meticulous editor but she assumed tasks that most journal editors would never bother to undertake. For example, she sought to check everything in the articles that the journal's editorial board accepted for publication. In preparing a memorandum for the guidance of the board in March 1983 at the end of her time as editor, she insisted: 'Future editors should be guided by Urry's Law: the correctness of quotations, footnotes and bibliography is inversely related to the fame of the author - and never trust members of the Editorial Board' ${ }^{101}$ But this was as much 'Barwick's Law' as her fellow editor's. Producing a journal prior to computerisation was undoubtedly a more arduous and time consuming task than it has become, but some of the tasks Barwick performed as the journal's editor were unnecessary. At least two members of the journal's editorial board during Barwick's time have described her as a master of supererogatory work. ${ }^{102}$ Whether this was so or not, it is undoubtedly true that she was, as Gunson remarked upon her untimely death, 'conscientious beyond the call of duty'. ${ }^{103}$

It appears that Barwick not only relished but resented the fact that the burdensome task of producing the journal largely fell on her shoulders. In the course of her seven-year reign as editor she threatened to resign on numerous occasions. The first of these occurred during the journal's first year of publication. 'I have worked nearly full time on this bloody journal since 24 May and I am totally fed up', Barwick angrily told Reece in October 1977. 'You and Markus can get

Pattern' and 'Foundations' with Stanner 1977). This said, Stanner did compliment Barwick upon all the hard work she had done on his essay: 'The editing is splendid - I congratulate you on it. Even I like this version' (Stanner to Barwick, undated [c. June 1977], his emphasis, Barwick Papers, Box 7, BARI02629). The manuscript version of the article carried an authorial note which stated that the paper had been 'revised by the editors [of the journal]', but this was omitted prior to its publication (cf the ms, held Barwick Papers, Box 7, BARI02630, with Stanner 1977: 3).

100 Barwick to Ryan, 19 September 1973, Barwick Papers, Series 10, Box 2, BARI01682; Barwick to Gunson, 20 August 1982 (unsent letter), Barwick Papers, Box 1, BARI00136; Reece 1986b: 71; Beckett 1986: 82; Stephen Foster, personal communication to author, 15 January 2012; Foster to author, 5 March 2012.

101 It seems that Barwick often tried to find solace in humour, which was perhaps one reason she cherished a paper Stanner wrote on Aboriginal humour in which he observed that '[laughter] is the good angel of enmity' (1986: 48). Several years earlier, Barwick had, half-jokingly, written to her long-time friend Jeremy Beckett: 'Got [your] paper [on George Dutton] on the first [August 1978] ... and checked the bibliography (nearly every entry wrong, you [...])' (Barwick to Beckett, 9 August 1978, Barwick Papers, Box 4, BARI02442).

102 More than one of Barwick's colleagues suggested to me that Barwick felt a need to have control over the journal's work. The documentary record lends some support to this claim (Urry, The McRae Paper: a note on a dispute, 5 April 1982, and Minutes of Aboriginal History Editorial Board Meeting, 24 February 1984, Gunson Papers; Urry to author, 7 February 2012; Foster to author, 5 March 2012).

103 Merlan to Barwick, 13 June 1978, Barwick Papers, Box 2, BARI02399; Gunson to Barwick, 28 July 1982, Barwick Papers, Box 1, BARI00136, original emphasis; Barwick, Aboriginal History: Editorial Responsibilities and Board Policy, 18 March 1983; Gunson to Foster, 15 April 1986; Williams 1986: 2; Reece 1986b: 71; Beckett 1986: 82; Anon 1987: 1; Foster, personal communication to author, 15 January 2012; Hercus, interview with author, 18 January 2012; Beckett to author, 7 February 2012. 
out the next issue. I have better uses for my time.' For several years Barwick never made good these threats, but by the middle of 1982 she was forced to recognise that she had no choice but to give up the editorship of the journal: her monograph on the history of Coranderrk awaited further revision, she was co-editing two collections of essays, and, most importantly, she had accepted a commission to write the opening volume of an Oxford History of Australia, which had to be completed by 1985 so that it was ready for publication by Australia's bicentenary. ${ }^{104}$

Following her resignation, Barwick helped see into publication the two collections of essays, which included two substantial essays of her own, but when she died suddenly of a cerebral haemorrhage in April 1986 she had neither completed the revision of her history of Coranderrk nor commenced the writing of the Oxford History volume. She had instead allowed herself to be distracted by bibliographical and biographical projects. These advanced the work of Aboriginal history and were typical of her generosity as a scholar but they might not have been the best use of her time. Certainly, her premature death - she was yet to turn 48 - robbed the continuing world of Aboriginal history of the considerable knowledge she had acquired but had yet to commit to paper. Her closest colleagues feel the loss to this day. ${ }^{105}$

In tendering her letter of resignation as the prinicipal editor of Aboriginal History, Diane Barwick expressed her appreciation of what Niel Gunson and Peter Grimshaw had done 'to create a new journal and a new discipline'. Yet, however much these two men and especially the former had laid the necessary groundwork for the journal and proven a sage guide, this achievement was primarily hers. Prior to the founding of Aboriginal History there had really been no such concept, let alone a historiographical movement. While Barwick had not been able to realise some of what she sought to bring about - for example, only a handful of the articles the journal had published can be described as truly interdisciplinary in nature - by the time she stepped aside as editor she had set down the direction that Aboriginal History has followed to this day. ${ }^{106}$

104 Barwick to Reece, 19 October 1977; Barwick File Notes, 31 October 1977; Barwick to Reece, Friday, 18 November 1977; Barwick to Reece, 21 November 1977; Barwick to Reece, 13 September 1978, Barwick Papers, Box 1, BARI02274; Barwick, Editors' Report, 17 November 1978; Contract for Vol. 1 of the Oxford History of Australia, January 1980, Barwick Papers, Series 22, Box 1, BARI02314; Barwick to Gunson, 22 July 1982, Barwick Papers, Box 5, BARI02468.

105 Barwick to Penny Taylor, Registrar, Australian Institute of Aboriginal Studies, 11 March 1985, Barwick Papers, Series 10, Box 1, BARI00008; Outlines for Oxford History of Australia Vol. 1, Barwick Papers, Series 22, Box 1, BARI02133; Barwick, Beckett and Reay 1985; Barwick 1985a; Barwick 1985b; White, Barwick and Meehan 1985; Beckett 1986: 82; Reece 1986b: 3-4; Laura and Richard Barwick, 'Editors' Preface', in Barwick 1998: x; Hercus, interview with author, 18 January 2012; Urry to author, 14 February 2012.

106 Barwick to Gunson, 22 July 1982; Gunson to Foster, 15 April 1986. 


\section{Whither Aboriginal history?}

This said, one might argue that Aboriginal History has been beset by a fundamental problem, and that the journal has never addressed, let alone attempted to resolve it. As I have already noted, Aboriginal history, as it was defined by the journal, involved a focus on Aboriginal people in terms of perspective. This approach entailed not only a way of seeing but an evaluation of the relative importance of this. In other words, a shift in perspective from the colonisers to Aboriginal people involved a greater assessment of the importance of what lay at the end of that point of view, namely the Aboriginal people or the Aboriginal world. However, it can be argued that this shift was and is not enough to sustain a field and its inquiry: a realignment of this kind, which is subjective in nature, demands a correlative in the objective world of the past if it is to realise the other meaning of perspective, namely being able to view things in their true relation or relative importance. Some of the practitioners of Aboriginal history sought to meet this requirement by emphasising the significance of the underlying social structures and cultural processes of Aboriginal communities, and thus the importance of the internal or domestic history of Aboriginal people, rather than the significance of political power, military capacity and economic strength and thus the relative importance of the objective relationship between the colonisers and the indigenous people, which was the approach adopted by historians of colonialism. Yet a focus on the autonomous world of Aboriginal people and its social and cultural dimensions can only illuminate so much about their post-colonial history, let alone the history of post-1788 Australia, since most Aboriginal communities lost their autonomy in the wake of the incursion of the European colonisers. This is to argue that a shift in perspective in the sense of adopting an Aboriginal-centric approach to the past did not and cannot meet the needs of perspective in its other sense, that of relative importance, or at least it cannot do so in the eyes of many historians. In this regard it is noteworthy that the account Henry Reynolds presented in his famous study The Other Side of the Frontier barely extended beyond the time of the first generation or so of contact.

In the decade following the founding of the journal, major political and intellectual changes occurred that were to have a major impact on its enterprise. Beginning in the early 1980s, Aboriginal spokespersons asserted that they should be the ones to tell the history of Aboriginal people, thereby challenging the right of white scholars to undertake research or at least the way in which they did their work. Younger white scholars, or at least those working in the discipline of history, were persuaded that they should not pursue research that focused on Aboriginal people and Aboriginal perspectives. By the early 1990s many had accepted the claim that Aboriginal history was Aboriginal people's business. (It has been claimed that the same phenomenon occurred in New Zealand in respect of Maori history. $)^{107}$ Consequently, there was a marked decline in the amount of historical research being conducted by historians that met the journal's definition of Aboriginal history. 
At much the same time the discipline of history in Australia was influenced by the ferment of postmodernism, which, apart from anything else, resulted in a marked growth in cultural and intellectual history as well as cultural studies. This, too, seems to have had a considerable impact on the amount of work being undertaken in the field of Aboriginal history as the journal defined it. A new wave of research focused on representation in one sense or another in order to examine the nature of European knowledge and its relationship to power. This had several strands. One examined the ways in which European explorers and discoverers sought to possess the land discursively, particularly through practices such as naming, mapping and surveying. The most influential study of this kind was Paul Carter's The Road to Botany Bay (1987). A second investigated the work of scientists, especially physical and social anthropologists, and their relationship to government policy and practice in Aboriginal affairs. The most notable studies in this regard were Russell McGregor's Imagined Destinies (1997) and Warwick Anderson's The Cultivation of Whiteness (2002). A third considered assimilation, largely in terms of the role it played in the governance of Aboriginal people, as for example in Tim Rowse's White Flour, White Power (1998). In the fourth strand, feminist historians posed questions about the relationships between white women and colonialism, particularly in respect of those who acted as missionaries, guardians or campaigners for the rights of Aborigines, as for instance in Fiona Paisley's Loving Protection? (2000). In a fifth strand, there were studies that considered the ways in which settlers had remembered or forgotten the Aboriginal past, as for example in Tom Griffiths' Hunters and Collectors (1996) and Chris Healy's From the Ruins of Colonialism (1997). A further strand, though this work had begun earlier, was research that focused on Anglo-Australian law. The most notable study here was Henry Reynolds' The Law of the Land (1987). Little, if any, of this work appeared in the pages of Aboriginal History. ${ }^{108}$

It might be argued that there are several means of addressing what I have suggested is a fundamental problem in the nature of Aboriginal history. One way is to champion a focus on the personal and the local, which is what those like Barwick, McBryde and Urry recommended. Yet such an approach tends to produce a patchwork of Aboriginal histories rather than a larger indigenous history. A second approach is to consider the ways in which the very concept of the Aborigines came into being, rather than taking Aboriginality for granted and thus treating it in an ahistorical manner. This involves tracing the ways in which an Aboriginal consciousness emerged as a social and cultural phenomenon in the context of the colonial encounter. This is what Reece recommended in his article 'Inventing Aborigines' and which I sought to do in The Making of the Aborigines (1989), where I argued that the way the pre-colonial aboriginal peoples came to acquire an Aboriginal consciousness in the post-colonial era should be the subject of inquiry. Yet there have been few studies of this phenomenon. More broadly, one might examine the ways in which Australian settler nationalism and Aboriginality have shaped or even helped to constitute one other. But perhaps

108 At the same time, the nature of the discipline of anthropology in Australia had changed enough for its journals to welcome historically oriented material, such as Cowlishaw 1990 and Morris 1990, which they might previously have rejected. 
even work of this kind will not resolve the problem described here. Consequently one might have to conclude that Aboriginal history, at least in the sense that this journal came to define it, is a very important yet rather circumscribed historical project.

\section{References}

AIAS Publications Committee, Australian Institute of Aboriginal and Torres Strait Islanders Studies, File Z73/7-3, Parts 3-6.

Anon 1987, 'Dedication', Aboriginal History 11: 1-8.

- 1979, 'Successful talk about Aboriginal oral history', AIAS Newsletter new series 12: 30-32.

Attwood, Bain 1989, The Making of the Aborigines, Allen \& Unwin, Sydney.

- 2003, Rights for Aborigines, Allen \& Unwin, Sydney.

- 2005, Telling the Truth about Aboriginal History, Allen \& Unwin, Sydney.

- 2011, 'Aboriginal History, minority histories and historical wounds: the postcolonial condition, historical knowledge and the public life of history in Australia', Postcolonial Studies 14: 171-186.

- and Tom Griffiths 2009, 'Frontier, race, nation', in Frontier, Race, Nation: Henry Reynolds and the History of Australia, Bain Attwood and Tom Griffiths (eds), Australian Scholarly Publishing, Melbourne: 3-52.

- and Andrew Markus 1999, The Struggle for Aboriginal Rights: a Documentary History, Allen \& Unwin, Sydney.

Barwick, Diane Papers, State Library of Victoria, MS 13521, Series 9, 10, 17, 22 and 4007.

- 1963, 'A little more than kin: regional affiliation and group identity among Aboriginal migrants in Melbourne', PhD thesis, Australian National University.

- 1978, 'A response to Dr [John] Hirst's suggestion of a biographical approach to the 1939-1988 volume', Australia 1938-1988 Bicentennial History Project Bulletin 2: 13-14.

- 1980, 'Current developments in Aboriginal History', paper delivered to ANZAAS Congress, Section 26, 16 May 1980 (copy held Diane Barwick Papers, State Library of Victoria, MS 13521, Series 3, Box 2, BARI00069). 
- 1981, 'Writing Aboriginal History: comments on a book and its reviewers', Canberra Anthropology 4(2): 74-86.

- 1983, 'How Prof Bill Stanner recruited a Canadian', Aboriginal Treaty News 9: 11.

- 1985a, 'This most resolute lady: a biographical puzzle', in Metaphors of Interpretation: Essays in Honour of WEH Stanner, Diane Barwick, Jeremy Beckett and Marie Reay (eds), Pergamon and The Australian National University Press, Sydney: 185-239.

- 1985b, 'Aunty Ellen: the pastor's wife', in Fighters and Singers: the Lives of Some Australian Aboriginal Women, Isobel White, Diane Barwick and Betty Meehan (eds), George Allen \& Unwin, Sydney: 175-199.

- 1988, 'Diane Elizabeth Barwick 1938-1986: a bibliography', Aboriginal History 12: 2-6.

- 1988, 'Making a treaty: the North American experience', Aboriginal History 12: 7-26.

- 1998, Rebellion at Coranderrk, Aboriginal History, Canberra.

- Jeremy Beckett and Marie Reay (eds) 1985, Metaphors of Interpretation: Essays in Honour of WEH Stanner, Pergamon and The Australian National University Press, Sydney.

- Michael Mace and Tom Stannage (eds) 1979, Handbook for Aboriginal and Islander History, Aboriginal History, Canberra.

Beckett, Jeremy 1986, ‘Obituary: Diane Barwick’, Oceania 57: 81-82.

Bell, Diane 1986, 'Barwick, Diane Elizabeth (1938-1986)', ANU Reporter, 9 May 1986: 6.

Blainey, Geoffrey 1975, Triumph of the Nomads: a History of Ancient Australia, MacMillan, Melbourne.

Chase, Athol 1979, ““Thomson time”', Aboriginal History 3: 109-110.

Corris, Peter 1966, 'Aborigines and Europeans in Western Victoria, from first Contacts to 1860 ', MA thesis, Monash University.

- 1968, Aborigines and Europeans in Western Victoria, Australian Institute of Aboriginal Studies, Canberra.

- 1969, 'Ethnohistory in Australia', Ethnohistory 16: 201-210. 
- 2000, Sweet and Sour, Southern Cross University Press, Lismore.

Cowlishaw, Gillian 1990, 'Helping anthropologists', Canberra Anthropology 13(2): $1-28$.

- 1992, 'Studying Aborigines: changing canons in anthropology and history', in Power, Knowledge and Aborigines, Bain Attwood and John Arnold (eds), La Trobe University Press, Melbourne: 20-31.

- 2006, 'On "getting it wrong": collateral damage in the History Wars', Australian Historical Studies 37: 181-202.

Curthoys, Ann 1973, 'Race and ethnicity: a study of the response of British colonists to Aborigines, Chinese and non-British Europeans in New South Wales, 1856-1881', PhD thesis, Macquarie University.

- 2008, 'WEH Stanner and the historians', in An Appreciation of Difference: WEH Stanner and Aboriginal Australia, Melinda Hinkson and Jeremy Beckett (eds), Aboriginal Studies Press, Canberra: 233-250.

Daly, Martin 1998, 'Truth's terrible tale', The Age, 18 April.

Davidson, JW 1966, 'Problems of Pacific History', Journal of Pacific History 1: 5-22.

Evans, Raymond et al 1975, Exclusion, Exploitation and Extermination: Race Relations in colonial Queensland, ANZ Books, Sydney.

Felton, Heather 1991, 'Beyond the frontier: an interview with Henry Reynolds', Island 49: 30-37.

Ferry, John 1979, 'The failure of the New South Wales missions to the Aborigines before 1845', Aboriginal History 3: 25-36.

Foster, SG and Margaret M Varghese 1996, The Making of the Australian National University, Allen \& Unwin, Sydney.

Frost, Alan 1981, 'New South Wales as terra nullius: the British denial of Aboriginal land rights', Historical Studies 19: 513-523.

Gale, Fay 1982, 'Community involvement and academics' response: the University of Adelaide Aboriginal Research Centre', Aboriginal History 6: 130-134.

Gallery of Aboriginal Australia: Report of the Planning Committee 1975, Australian Government Printing Service, Canberra.

Gunson, Niel Papers, Personal Collection. 
- 1959, 'Evangelical missionaries in the South Seas 1797-1860', PhD thesis, Australian National University.

- 1960-61, 'The Nundah missionaries', Royal Historical Society of Queensland Journal 6: 511-539.

- 1968, The Good Country: Cranbourne Shire, Cheshire, Melbourne.

- 1974, Australian Reminiscences and Papers of L.E. Threlkeld, Missionary to the Aborigines, 1824-1859, Australian Institute of Aboriginal Studies, Canberra, vol. 1.

- 1981, 'Proud shoes: black family history', Aboriginal History 5: 147-152.

- 1985, 'Diane Barwick', Aboriginal History 9: 4-5.

- 2000, 'The imprimatur of Charles Perkins on Aboriginal History', Aboriginal History 24: 258-259.

- 2003, “"Leave it to me”: an appreciation of Peter John Grimshaw, 1932-2003', Aboriginal History 27: 245-246.

- 2006, 'Hexagonal reflections on Pacific History', in The Coombs: a House of Memories, Brij V Lal and Allison Ley (eds), Research School of Pacific Studies, Australian National University, Canberra: 69-77.

Harkin, Michael E 2010, 'Ethnohistory's ethnohistory: creating a discipline from the ground up', Social Science History 34: 113-128.

Hartwig, Mervyn 1978, 'Theoretical history by osmosis: the language of common sense and the comparative history of "race relations" in Australia and New Zealand', Aboriginal History 2: 167-172.

Hasluck, Paul 1942, Black Australians: a Survey of Native Policy in Western Australia, 1829-1897, Melbourne University Press, Melbourne.

Haviland, John and Leslie 1980, "“How much food will there be in heaven": Lutherans and Aborigines around Cooktown before 1900', Aboriginal History 4: 119-149.

Hercus, Luise 1969, The Languages of Victoria: a Late Survey, Australian Institute of Aboriginal Studies, Canberra.

- and Peter Sutton 1986, This is What Happened: Historical Narratives by Aborigines, Australian Institute of Aboriginal Studies, Canberra.

Howe, Kerry 2003, ‘Two worlds?', New Zealand Journal of History 37: 50-61. 
Johnson, Bowman and Andrew Markus 1987, 'Growing up in Queensland: Bowman Johnson talks to Andrew Markus', Aboriginal History 11: 77-81.

Kerin, Rani 2007, "“Mixed up in a bit of do-goodery": Judy Inglis, activist, anthropology and Aboriginal History', History and Anthropology 18: 427-442.

Kijas, Johanna 1992, ‘Diane Barwick: the influential outsider, a pioneer in writing Aboriginal History', The Olive Pink Society Bulletin 4(2): 5-13.

- 1993, 'An "unfashionable concern with the past": the historical anthropology of Diane Barwick', MA thesis, University of Melbourne.

- 1997, 'An "unfashionable concern with the past": the historical anthropology of Diane Barwick', Australian Aboriginal Studies 1: 48-60.

Kolig, Erich 1979, 'Captain Cook in the Western Kimberleys', in Aborigines of the West: Their Past and their Present, RM and CH Berndt (eds), University of Western Australia Press, Perth: 274-282.

Loos, Noel 1980, 'Queensland's kidnapping act: the Native Labourers Protection Act of 1884', Aboriginal History 4: 150-173.

Lyons, Gregory 1983, 'Official policy towards Victorian Aborigines 1957-1974', Aboriginal History 7: 61-79.

MacDougall, David 1976, Tapes recorded at Moree, New South Wales, and adjacent areas, Australian Institute of Aboriginal and Torres Strait Islander Studies Library, MacDougall D01.

Macintyre, Stuart 2010, The Poor Relation: a History of Social Sciences in Australia, Melbourne University Press, Melbourne.

McBryde, Isabel 1966, 'An archaeological survey of the New England region', PhD thesis, University of New England.

- 1974, Aboriginal Prehistory in New England: an Archaeological Survey of Northeastern New South Wales, Sydney University Press, Sydney.

- (ed) 1978, Records of Times Past: Ethnohistorical Essays on the Culture and Ecology of the New England Tribes, Australian Institute of Aboriginal Studies, Canberra.

- 1985, 'Introduction', in Who Owns the Past? Papers from the Annual Symposium of the Australian Academy of the Humanities, Isabel McBryde (ed), Oxford University Press, Melbourne: 1-10.

- 1996, 'Perspectives of the past: an introduction', in Terrible Hard Biscuits: a Reader in Aboriginal History, Valerie Chapman and Peter Read (eds), Allen \& Unwin, Sydney: 1-15. 
ABORIGINAL HISTORY 2012 VOL 36

McMillen, Christian 2007, Making Indian Law: the Hualapai Land Case and the Birth of Ethnohistory, Yale University Press, New Haven.

McQueen, Humphrey 1974, Aborigines, Race and Racism, Penguin, Melbourne.

Markus, Andrew 1974, From the Barrel of a Gun: the Oppression of the Aborigines, 1860-1900, Victorian Historical Association, Melbourne.

- 1977, 'Through a glass darkly: aspects of contact history', Aboriginal History 1: 170-180.

- 1979, Fear and Hatred: Purifying Australia and California, 1850-1901, Hale \& Iremonger, Sydney.

- 1986, Blood from a Stone: William Cooper and the Australian Aborigines' League, Monash Publications in History, Melbourne.

- 1990, Governing Savages, Allen \& Unwin, Sydney.

- and Curthoys, Ann (eds) 1978, Who are our Enemies? Racism and the Australian Working Class, Hale \& Iremonger, Sydney (a special issue [no 35] of Labour History).

Montgomerie, Deborah 1997, 'Beyond the search for good imperialism: the challenge of comparative ethnohistory', New Zealand Journal of History 31: 153-168.

Morris, Barry 1990, 'Making histories/living histories', Social Analysis 27: 83-92.

Muecke, Stephen, Alan Rumsey and Banjo Wirrunwarra 1985, 'Pigeon the outlaw: history as texts', Aboriginal History 9: 81-100.

Mulvaney, DJ 1969, The Prehistory of Australia, Thames and Hudson, London; revised edition, Penguin, Melbourne, 1975.

- 2011, Digging up the Past, University of New South Wales Press, Sydney.

Museums in Australia 1975: Report of the Committee of Inquiry on Museums and National Collections, Australian Government Printing Service, Canberra.

National Collections: Submission to Cabinet, 12 December 1973, National Archives of Australia, Series A5915, Item 846.

Nelson, Hank 1966, 'Early attempts to civilise the Aborigines of the Port Phillip District', MEd thesis, University of Melbourne. 
Peterson, Nicolas 2006, 'Repositioning anthropology, 1972-1980', in A Future for Archaeology: the Past in the Present, Robert Layton et al (eds), UCL Press, London: 31-39.

Ramson, WS1988, The Australian National Dictionary: a Dictionary of Australianisms on Historical Principles, Oxford University Press, Melbourne.

Read, Peter 1990, Charles Perkins: a biography, Viking, Sydney.

Reece, RHW Papers, Personal Collection.

- 1969, 'The Aborigines and colonial society of New South Wales before 1850', MA thesis, University of Queensland.

- 1974, Aborigines and Colonists: Aborigines and Colonial Society in New South Wales in the 1830s and 1840s, Sydney University Press, Sydney.

- 1976. 'The Aborigines in Australian historiography', Australian Institute for Aboriginal and Torres Strait Islander Studies Library, PMS 1447 (later published in Historical Disciplines and Culture in Australasia, John A Moses (ed), University of Queensland Press, St Lucia: 253-281).

- 1977, 'The cession of Sarawak to the British crown in 1946', PhD thesis, Australian National University.

- 1979, 'Review of The Two Worlds of Jimmie Barker', Aboriginal History 3: 161-163.

- 1982, Aboriginal community history: a cautionary tale, unpublished paper, Australian Institute for Aboriginal and Torres Strait Islander Studies Library, PMS 4070.

- 1986a, 'Notes on the news for 9 April 1986', Australian Institute for Aboriginal and Torres Strait Islander Studies Library, PMS 4155.

- 1986b, 'Diane Barwick', Australian Aboriginal Studies 2: 70-72.

- 1987, 'Inventing Aborigines', Aboriginal History 11: 14-23.

Reynolds, Henry 1976, 'The other side of the frontier: early Aboriginal reactions to pastoral settlement in Queensland and Northern New South Wales', Historical Studies 17: 50-63.

- 1978a, 'Aboriginal-European contact history: problems and issues', Journal of Australian Studies 3: 52-64.

- 1978b, "Before the instant of contact": some evidence from nineteenthcentury Queensland', Aboriginal History 2: 63-69. 
- 1983, 'Aborigines and European social hierarchy', Aboriginal History 7: 124133.

Rowley, Charles 1970a, The Destruction of Aboriginal Society, Australian National University Press, Canberra.

- 1970b, Outcasts in White Australia, Australian National University Press, Canberra.

Rowse, Tim 2000, Obliged To Be Difficult: Nugget Coombs' Legacy in Indigenous Affairs, Cambridge University Press, Melbourne.

- 2007, 'Barwick, Diane Elizabeth (1938-1986)', Australian Dictionary of Biography, vol 17, <http://adb.anu.edu.au/biography/barwick-diane-elizabeth-76/ text21837>, accessed 25 January 2012.

Sears, Laurie J 1993, 'The contingency of autonomous history', in Autonomous Histories, Particular Truths: Essays in Honor of John R.W. Smail, Laurie J Sears (ed), University of Wisconsin, Center for Southeast Asian Studies, Madison: 3-35.

Smail, John RW 1961, 'On the possibility of an autonomous history of modern Southeast Asia', Journal of Southeast Asian History 2(2): 72-102.

Stannage, Tom 1979, The People of Perth: a Social History of Western Australia's Capital City, Carroll's for Perth City Council, Perth.

Stanner, WEH Papers, Australian Institute of Aboriginal and Torres Strait Islander Studies Library, MS 3752, Series 1 and 18.

- 1969, After the Dreaming: the 1968 Boyer Lectures, Australian Broadcasting Commission, Sydney.

- 1977, “"The history of indifference thus begins"”, Aboriginal History 1:3-26.

- 1986, 'Aboriginal humour', Aboriginal History 6: 39-48.

- and Diane Barwick 1979, 'Not by eastern windows only: anthropological advice to Australian governments in 1938', Aboriginal History 3: 37-61.

Sutton, Peter 1988, 'Myth as history, history as myth', in Being Black: Aboriginal Cultures in Settled Australia, Ian Keen (ed), Aboriginal Studies Press, Canberra: 251-268.

Thomson, Alistair 2007, 'Four paradigm transformations in oral history', The Oral History Review 34: 49-70. 
Urry, James 1978, Comments on Henry Reynolds, Aboriginal-European contact history, James Urry Personal Papers.

- 1979, 'Beyond the frontier: European influence, Aborigines and the concept of "traditional culture"', Journal of Australian Studies 5: 2-16.

White, Isobel, Diane Barwick and Betty Meehan (eds) 1985, Fighters and Singers: the Lives of Some Australian Aboriginal Women, George Allen \& Unwin, Sydney.

Williams, Nancy 1986, 'Diane Barwick, 1938-1986', Canberra Anthropology 9(1): $1-3$.

Working Party of Aboriginal Historians for the Bicentennial History 1981, 'Aboriginal history and the bicentennial volumes', Australia 1939-1988: A Bicentennial History Bulletin 3: 21-35. 